MORALES, Ana María. "La política criminal contemporánea:

Influencia en Chile del discurso de la ley y el orden".

Polit. crim. Vol. 7, № 13 (Julio 2012), Art. 3, pp. 94 - 146.

[http://www.politicacriminal.cl/Vol_07/n_13/Vol7N13A3.pdf]

\title{
La política criminal contemporánea: Influencia en Chile del discurso de la ley y el orden.*
}

\author{
Ana María Morales Peillard \\ Magíster en Política Criminal, London School of Economics and Political Science, \\ Docente del Magíster en Derecho Penal, Universidad de Talca \\ amoralespeillard@gmail.com
}

\section{Resumen}

El presente artículo busca responder algunas preguntas relativas a la política criminal contemporánea. Una de ellas, busca determinar si las políticas de control penal establecidas en Chile durante las últimas dos décadas, podrían ser calificadas como punitivas; mientras que la segunda apunta a responder si las explicaciones otorgadas por algunas visiones criminológicas comparadas, tendientes a justificar los dramáticos cambios observados en el campo del control del delito en los últimos treinta años, sirven de base para racionalizar las modificaciones observadas en Chile, o si existen explicaciones de carácter local que además debieran ser consideradas.

Para indagar en relación al primer propósito, se expone brevemente el desarrollo criminológico y político criminal del país, desde la primera mitad el siglo XX hasta fines de la década pasada; mientras que para la segunda, se expone algunas connotadas teorías utilizadas en el ámbito académico a fin de explicar los cambios político-criminales y se analiza su pertinencia para explicar nuestra realidad.

\section{Palabras clave}

Política criminal chilena, la ley y el orden, populismo punitivo, seguridad ciudadana

\begin{abstract}
The present article aims at answering some questions related to contemporary criminal justice policy. One of them seeks to determine whether the penal control policies established in Chile during the last two decades, could be classified as punitive; while the second one tries to answer whether the explanations given by some compared criminological visions to justify the dramatic changes observed in the field of crime control in the past decades, are useful to understand the changes observed in Chile, or if there are other explanations of a local character that should also be considered.
\end{abstract}

\footnotetext{
* El presente artículo toma como base la monografía presentada por la autora para optar al grado académico de Master in Science in Criminal Justice Policy, otorgado por la London School of Economics and Political Science de la Universidad de Londres, en 2007.
} 


\section{MORALES, Ana María. "La política criminal contemporánea:} Influencia en Chile del discurso de la ley y el orden".

In order to do research, in relation to the first objective, the article reviews briefly the development of the criminological and the penal policies of this country, during the XX century until the past decade; while for the second one, some renowned theories in the academic field are discussed to explain the changes in criminal justice policies, while it analyses their pertinence in order to explain our reality.

\section{Key words}

Criminal Justice Policy in Chile, Law and order, populist punitiveness, citizen security

\section{Introducción}

Las últimas décadas han visto surgir una literatura académica fértil que ha buscado explicar los cambios contemporáneos, observados en el campo del control del delito. En su mayor parte, se ha concentrado en los cambios observados en Estados Unidos y en el Reino Unido, y ha tratado de explicar su "vuelco punitivo", ratificado principalmente por la existencia de altas tasas de prisionización en el primero y por un aumento sostenible de la mismas en el segundo. La mayor parte de esta literatura, como señala Brown, no ha centrado sus explicaciones sólo en la arena de la justicia penal, sino que se ha situado en el contexto de cambios generales en la organización social, política, económica y cultural, en resumen, las condiciones de la "modernidad tardía". 12

Ejemplos de este análisis se puede encontrar en el trabajo de autores tales como, "La Sociedad Exclusiva" de Young o "La cultura del Control" de Garland; que, a su vez, se han convertido en lecturas obligatorias en el análisis de las políticas criminales contemporáneas. Adicionalmente, en el contexto hispano, también se puede encontrar interpretaciones a esas tendencias, algunas de las cuales se han apoyado en la tesis de Garland como es el caso de Diez en "El nuevo modelo de la Seguridad Ciudadana". Otras, como la de Silva, si bien toman algunos de los elementos citados por el autor escocés, ven en el fenómeno de la globalización una serie de problemáticas que a su vez demandan un cambio de las políticas criminales inspiradas en el derecho penal liberal.

Considerando dicho contexto, en el presente artículo no se pretende efectuar un análisis extenso de las explicaciones dadas por esos autores, toda vez que sus tesis han sido examinadas por variadas obras, sino que su intención es, en cambio, a través de su visión, encontrar una respuesta para algunas de las preguntas que fluyen en la mente de la autora, cada vez que lee alguna construcción relacionada con ese tema: ¿Está sucediendo lo mismo en Chile? Y, si son reales estos temores de que en realidad están sucediendo cambios serios

\footnotetext{
${ }^{1}$ BROWN, David, "Continuity, rupture, or just more of the "volatile and contradictory"? Glimpses of New South Wales penal practices behind and through the discursive" en: PRATT, John; BROWN, David; BROWN, Marc; HALLSWORTH, Simon, MORRISON, Wayne, (Eds.), The New Punitiveness. Trends, theories and perspective, Cullompton: Willan, 2005, p. 27.

${ }^{2}$ Como señala Zedner, en la teoría penal y en muchas otras disciplinas "se ha dedicado mucha energía a establecer si esto significa el comienzo de una modernidad tardía, la agonía de la modernidad, o la llegada de la post modernidad". ZEDNER, Lucia, "Dangers of Dystopia in Penal Theory", Oxford Journal of Legal Studies 22 (2) (2002): 341-366, p. 341.
} 
Polit. crim. Vol. 7, № 13 (Julio 2012), Art. 3, pp. 94 - 146.

[http://www.politicacriminal.cl/Vol_07/n_13/Vol7N13A3.pdf]

en la política criminal, ¿se pueden atribuir a algunas de estas explicaciones, o deberían buscarse algunas más locales?

Con el propósito mencionado anteriormente, en el primer capítulo se describirá brevemente el contexto histórico chileno en relación a las políticas criminales adoptadas por el Estado a través de su historia. Luego, se describirá algunos de los cambios contemporáneos que pueden observarse en esta materia en el país, poniendo especial énfasis en las circunstancias políticas que han rodeado su adopción. Además, se presentará algunos ejemplos de las estrategias penales desarrolladas en las últimas dos décadas, con acento en las múltiples iniciativas legislativas observadas en dicha área, durante ese período.

En el segundo capítulo, se procurará buscar algunas respuestas para los cambios observados en la arena política criminal, donde se analizará algunas de las proposiciones dadas por los mencionados especialistas y también otras que resultan pertinentes.

\section{El contexto histórico de la política criminal chilena.}

En la sección siguiente, se procurará entregar una descripción de las políticas criminales chilenas, su desarrollo a través del siglo veinte, y su orientación durante la primera década del presente siglo.

\subsection{Desarrollo de la criminología y las políticas públicas en materia criminal.}

A comienzos del siglo XX, el campo de la política criminal y la criminología en Chile, aunque escaso, estaba fuertemente concentrado en bases positivistas. La tesis Lombrosiana había encontrado algunos seguidores entusiastas en esta parte del hemisferio, en especial porque daba un apoyo científico a las percepciones e impresiones negativas sobre las clases populares que habían estado arraigadas por mucho tiempo. ${ }^{3}$ Palabras como "tratamiento" y "rehabilitación" eran comúnmente usadas por criminólogos e, incluso, por políticos, y a su vez inspiraron la reforma penitenciaria de fines del siglo XIX. ${ }^{4}$ Sin embargo, esta transformación se implementó de manera frágil, pues no estuvo acompañada de los recursos económicos necesarios. En efecto, la Penitenciaría de Santiago, que parecía ser un lugar que daría más alternativas a los internos en comparación a otras prisiones chilenas, como señala Correa, presentó proyectos de rehabilitación muy limitados (en forma de talleres), débil inspección y precarias condiciones de vida para los internos. ${ }^{5}$

También, entre las décadas de 1920 y 1930, comenzaron a ganar terreno aquellas posiciones que buscaban destacar la importancia del contexto social como causa de la

\footnotetext{
${ }^{3}$ LEÓN, Marco Antonio, Los dilemas de una Sociedad cambiante: criminología, criminalidad y justicia en el Chile contemporáneo 1911-1965, Revista Chilena de Historia del Derecho 19 (2003/2004): 223-277, p. 225.

${ }^{4}$ Esta reforma penitenciaria tenía como objetivo terminar con las influencias coloniales, que conllevaban prácticas tales como el castigo corporal, ejecuciones públicas, el uso de tormentos y la humillación de los prisioneros; similares a aquellas prácticas del siglo XVIII en Europa, descritas por Foucault. FOUCAULT, Michel, Vigilar y Castigar, Madrid: Siglo XXI, 2005.

${ }^{5}$ CORREA, María José, "Demandas penitenciarias. Discusión y reforma de las cárceles de mujeres en Chile (1930-1950) Historia (Revista del Instituto de Historia de la Pontifica Universidad Católica de Chile) 38(1) (2005): 9-30, p. 25.
} 
MORALES, Ana María. "La política criminal contemporánea: Influencia en Chile del discurso de la ley y el orden".

delincuencia. ${ }^{6}$ Sin embargo, esas corrientes se observaron más a nivel del pensamiento criminológico (reproduciendo las opiniones de especialistas extranjeros), que en el campo de la investigación o en las políticas públicas implementadas. Aún más, como plantea León:
"después de la convulsionada segunda mitad de la década de 1920, y la crisis económica que afectó los comienzos del decenio siguiente, el pesimismo cultural y social se trasladó a quienes evaluaban el país en función de potenciar las virtudes raciales. En este contexto, las ideas sobre estigmatizar ciertas características físicas cobraron un renovado auge". 7

Durante la década de los años 30, comenzó a tener gran presencia en Chile, la tesis vinculada con la Defensa Social. Esta visión, heredada por el positivismo después de la escuela clásica, ${ }^{8}$ tuvo como fin, el proteger a la sociedad del delincuente, pero también el proteger al individuo del peligro de caer o recaer en la delincuencia. ${ }^{9}$ En este enfoque, el delito constituye un daño para la sociedad, y quien lo comete, un elemento negativo y disfuncional del sistema social, y donde la pena no sólo tiene la función de retribuir sino también debe prevenir, a través de una misión resocializadora de la sanción. ${ }^{10}$ En ese contexto, las mayores críticas efectuadas a la tesis de la defensa social apuntan a sus construcciones peligrosistas, que en definitiva permitieron justificar la aplicación de medidas de seguridad o sentencias indeterminadas con el objeto de prevenir o erradicar la peligrosidad, aunque en su vertiente positivista se le reconoce el haber puesto énfasis en la función resocializadora de la sanción.

Este discurso permeó fuertemente a nivel académico y fue así como en el país se creó incluso un Instituto de Defensa Social en aquella época. ${ }^{11}$ En el plano político criminal, también buscaron imponerse estas tesis, y es así como se comenzaron a formular críticas al Código Penal, considerando que la codificación de 1874 respondía a una lógica de corte clásico. De esta forma, surgieron desde la academia y el Poder Judicial algunas voces que abogaron por su reforma, argumentando que se trataba de una legislación que carecía de "armas de lucha contra el crimen". ${ }^{12}$ En ese contexto, y en particular durante la dictadura de

\footnotetext{
${ }^{6}$ LEÓN, "Los dilemas”, cit. nota no 3, p. 230.

${ }^{7}$ LEÓN, "Los dilemas", cit. nota no 3, p. 230.

${ }^{8}$ BARATTA, Alessandro, Criminología crítica y crítica del Derecho Penal, Buenos Aires: Siglo veintiuno Editores, 2002, p. 36.

${ }^{9}$ DEL OLMO, Rosa, América Latina y su criminología, D.F. México: Siglo veintiuno Editores, 1999, p.179.

${ }^{10}$ En ese sentido, como explica Baratta, las diferencias de enfoque entre la escuela liberal clásica y la positiva en relación a la teoría de la defensa social, no reside tanto en el contenido ideológico ni en los valores fundamentales considerados dignos de tutela, sino más bien en la actitud metodológica respecto de la explicación de la criminalidad. Así, en el caso de la primera, su estudio se centra en el crimen, mientras que la segunda enfoca su estudio en el criminal, aunque ambas consideran la actitud interior o culpabilidad como un principio fundamental, el cual en la escuela liberal adquiere un significado moral-normativo (disvalor, condena moral) y en la positiva un contenido sociopsicológico (revelador de la peligrosidad social). BARATTA, Criminología crítica y crítica, cit. nota $n^{\circ} 8$, pp. 36-38.

${ }^{11}$ DEL OLMO, América Latina, cit. nota ${ }^{\circ}$ 9, p. 183.

12 FONTENCILla, Rafael, El Código Penal Chileno ante las nuevas orientaciones de la Ciencia Penal, Santiago: Imp. Lagunas \& Quevedo Ltda. , 1932, p. 10. Cit.: MATUS, Jean Pierre "La Doctrina penal de la (fallida) recodificación chilena del siglo XX y principios del XXI”, Política Criminal, 5(9), 2010, pp. 143206, p. 168.
} 
Polit. crim. Vol. 7, № 13 (Julio 2012), Art. 3, pp. 94 - 146.

[http://www.politicacriminal.cl/Vol_07/n_13/Vol7N13A3.pdf]

Carlos Ibáñez del Campo (1927-1931), se encargó la redacción de un nuevo Código Penal a una comisión convocada por el Ministerio de Justicia, la que sólo sesionó una vez. Posteriormente, y en la misma línea, hubo dos intentos de codificación, uno de los cuales prosperó y fue enviado al Congreso Nacional para su discusión en 1929. Dicho proyecto, elaborado por Erazo y Fontecilla, fue fruto de una comisión convocada nuevamente por dicha cartera. El citado proyecto no sólo contenía las propuestas de la escuela de política criminal para reducir las penas cortas de prisión por sustitutos penales como la multa, el perdón judicial, y la condena condicional, sino también proponía la inclusión de un "estado peligroso" que servía de base para la imposición de medidas de seguridad (internamiento en manicomios u hospitales, establecimientos de reeducación, casas de salud, casas de trabajo, expulsión del extranjero, y sujeción a la vigilancia de la autoridad, entre otras medidas) frente a casos de peligro, pero que no fueren constitutivos de delito. ${ }^{13}$ En el mismo sentido, el proyecto contemplaba la posibilidad de imponer condenas indeterminadas en el caso de reincidentes, entre otras propuestas. Sin embargo, considerando la anormalidad institucional propia de la dictadura, y el contexto de crisis económica de la época, la iniciativa en definitiva no prosperó en su discusión ante el Congreso Nacional.

Posteriormente, bajo el segundo gobierno de Arturo Alessandri, en 1938, hubo un nuevo intento de recodificación del Código Penal, encargado por el Ministerio de Justicia a una comisión. El proyecto, elaborado por Silva y Labatut, constituía más bien una revisión del código vigente, sin buscar romper con su estructura, aun cuando también contenía, conforme la tendencia positivista, un sistema de "medidas de seguridad y corrección", consistente en la posibilidad de decretar el internamiento en manicomios u hospitales, además de regular la peligrosidad y la reincidencia como criterios relevantes para efectos de determinar la sanción aplicable. Finalmente, no obstante haberse completado el proyecto, éste no prosperó, al carecer de apoyo político por parte del gobierno siguiente. ${ }^{14}$

Como se puede observar, a pesar de la importante influencia del positivismo a nivel ideológico, ésta corriente no logró materializarse en un nuevo código punitivo. Sin embargo, sí es posible rastrear su influencia en otras legislaciones que recogieron sus postulados, como se desprende de la Ley $\mathrm{N}^{\circ} 4.447$ sobre protección de menores de 1928, y especialmente, a nivel de la ejecución penal, del Decreto Ley $\mathrm{N}^{\circ} 321$ que reguló el cumplimiento progresivo de la pena a través de la incorporación de la libertad condicional, y de la Ley $\mathrm{N}^{\mathrm{o}} 7.821$ de 1944, que estableció la remisión condicional de la pena, para los casos de primerizos que hubieren cometido delitos menores, con el objeto de "evitar el contagio moral de los delincuentes primarios del tipo ocasional". 15 Por otro lado, como precisa Matus, también en el mismo se buscó ejercer un mayor control político a través de la sanción penal en normas como el Decreto Ley $N^{\circ} 425$ de 1925, relativo a los abusos de publicidad, y la Ley $\mathrm{N}^{\circ} 8.987$, o de Defensa permanente de la Democracia, dictada en $1948 .^{16}$

\footnotetext{
${ }^{13}$ MATUS, "La Doctrina penal", cit. nota ${ }^{\circ} 12$, p. 174

${ }^{14}$ Sobre el particular véase MATUS, "La Doctrina penal", cit. nota ${ }^{\circ} 12$.

${ }^{15}$ Mensaje del proyecto de ley. Cit.: MATUS, Jean Pierre, "El Positivismo en el Derecho Penal Chileno. Análisis sincrónico y diacrónico de una doctrina de principios de del siglo XX que se mantiene vigente", Revista de Derecho, 20 (1) (2007): 175-2003, p. 189.

${ }^{16}$ MATUS, "La Doctrina penal", cit. nota $n^{\circ} 12$.
} 


\section{MORALES, Ana María. "La política criminal contemporánea:} Influencia en Chile del discurso de la ley y el orden".

En la misma línea, a instancias del Instituto de Ciencias Penales, ${ }^{17}$ se aprobó la Ley No11.625 de 1954 "sobre estados antisociales y medidas de seguridad". Esta legislación, nunca entró en vigor -salvo sus títulos II y III que contenían algunas medidas represivas--, ${ }^{18}$ pues no se contaba con la infraestructura necesaria para llevarla a cabo. En ella se contemplaban un conjunto de medidas de seguridad tanto pre como post delictuales, destinadas a prever la conducta criminal o castigar a los homosexuales, los toxicómanos, los vagos, los ebrios, los que falseasen su identidad y aquéllos que ya habían sido condenados y se encontraban en situaciones sospechosas, como poseer bienes cuyo origen no pudiesen justificar;" en definitiva "determinadas personas, que constituyen, realmente, un peligro para la sociedad y que son, por así decirlo, el caldo de cultivo de delincuentes, de gente que más tarde ha de cometer delitos".20

La influencia de la tesis de la Defensa Social en la política criminal chilena y en particular en la legislación, fue sin duda importante, y como se observará más adelante, su influjo se puede rastrear incluso en la década de los 80. Sin embargo, como plantea León, más allá de plasmarse en la legislación, en realidad, "medidas más inmediatas como dotar de mayor presupuesto a Carabineros, Investigaciones, y al Servicio de Prisiones terminaban siendo aplazadas o sólo resueltas en partes". 21

Incluso, la prensa recalcaba el efecto de la deplorable situación penitenciaria como un factor que influía en el aumento de la criminalidad. En esa línea, las condiciones de las cárceles eran tan malas que un juez, a comienzos de los años 50, se refirió a ellas como un "vivero de criminales". 22

Esta situación se veía agravada por la aplicación de un Código Penal anacrónico que no obstante los intentos por sustituirlo, no logró reflejar los cambios sociales experimentados en la primera mitad del siglo veinte o los desarrollos criminológicos observados comparativamente. Como indica León "la redefinición de quienes eran delincuentes o criminales, no fue asumida por una legislación que insistió en la idea de reprimir más que en rehabilitar, a pesar que esta había sido ampliamente discutida". ${ }^{23}$

Si bien no se cuenta con mayor información disponible sobre los avances criminológicos y político criminales durante las décadas posteriores, todo parece indicar que no hubo mayores cambios en esta arena entre los años 1960 y 1970. Así, por lo menos en lo que dice relación con el Código Penal, no hubo más intentos recodificadores durante la segunda mitad del Siglo XX. En ese sentido, como afirman algunos autores, lo cierto es que en dicho período todo parece indicar que los cambios legislativos se concentraron en generar

\footnotetext{
${ }^{17}$ MATUS, "El Positivismo", cit. nota n' 15, p. 189.

${ }^{18}$ MATUS, "La Doctrina penal", cit. nota $\mathrm{n}^{\circ} 12$.

19 CANDINA, Azun, "Seguridad Ciudadana y Sociedad en Chile Contemporáneo. Los delincuentes, las políticas y los sentidos de una sociedad", Revista de Estudios Históricos, 2(1) (2005), s/p.

${ }^{20}$ Libro de sesiones ordinarias del Senado, junio de 1954, Tomo I, p. 294. Cit.: CANDINA, "Seguridad Ciudadana", cit. nota ${ }^{\circ} 19, \mathrm{~s} / \mathrm{p}$.

${ }^{21}$ LEÓN, "Los dilemas", cit. nota no 3, p. 250.

${ }^{22}$ El Mercurio Valparaíso, 29 de julio, 1952. Cit.: LEÓN, "Los dilemas", cit. nota no 3, p. 250.

${ }^{23}$ LEÓN, "Los dilemas", cit. nota n 3, p. 276.
} 
Polit. crim. Vol. 7, № 13 (Julio 2012), Art. 3, pp. 94 - 146.

[http://www.politicacriminal.cl/Vol_07/n_13/Vol7N13A3.pdf]

modificaciones más estructurales, asociadas a una distribución más equitativa del ingreso, mediante cambios en materia agraria, de salud y de educación. ${ }^{24}$ Así, a medida que la agitación social empezó a expandirse, el esfuerzo de los gobiernos se concentró en direccionar su tránsito hacia los cambios político-económicos deseados.

Por otro lado, esos lentos cambios observados en el campo criminológico a lo largo del siglo pasado, mantuvieron su letargo durante la dictadura militar, cuyas políticas criminales se concentraron fundamentalmente en abordar al denominado "enemigo interno". En efecto, durante dicho período, las energías del gobierno de la época se enfocaron hacia una represión de los disidentes del régimen, lo que se tradujo en que no se implementaran políticas relevantes en esta materia. Como señala Hernández, el régimen autoritario prácticamente no intervino en los fundamentos legislativos del sistema penal y mantuvo una actitud "más bien conservadora" frente a la legislación existente, aun cuando se conocieron algunas iniciativas de corte populista. ${ }^{25}$ De esta forma, en el citado régimen, la política criminal no se concentró en la delincuencia común, si no como señala el mismo autor, se orientó a endurecer el derecho penal político. ${ }^{26}$

Una importante excepción la encontramos en la promulgación de la Ley $\mathrm{N}^{\mathrm{o}} 18.216$ sobre medidas alternativas a la pena privativa de la libertad, que recogió en parte, lo regulado en la citada Ley $\mathrm{N}^{\mathrm{o}} \mathrm{N}^{\mathrm{o}} 7.821$ sobre remisión condicional de la pena. Esta normativa, inspirada al igual que en otras épocas en la filosofía de la defensa social, con su eje en la peligrosidad y el correccionalismo, ${ }^{27}$ también se vio influenciada por las bases teóricas de la criminología crítica, que apuntaban al desarrollo de procesos de descriminalización, despenalización, desjudicialización, y de programas de diversión, planteados -entre otros motivos- con el objeto de restringir el uso de la prisión. ${ }^{28}$ Sin embargo, más allá de esta influencia, el fundamento principal de su introducción, fue más bien el de descomprimir los problemas de sobrepoblación, que el generar una contribución en términos de la resocialización o de reconocimiento de los derechos de los penados. ${ }^{29}$ Adicionalmente, y al igual que otras iniciativas en esta materia, su implementación se llevó a cabo sin un financiamiento que asegurara su efectividad. ${ }^{30}$

Como se puede observar, nuestra legislación política criminal, hasta la década de los 80 inclusive, se mantuvo fuertemente arraigada en concepciones positivistas con énfasis

\footnotetext{
${ }^{24}$ MATUS, "La Doctrina penal", cit. nota $n^{\circ} 12$.

25 Como sería el caso de los aumentos de penas en relación a los delitos sexuales y contra la libertad ambulatoria, y el reimpulso de la pena de muerte. HERNÁNDEZ, Héctor, "El Derecho Penal chileno en el cambio de siglo: Ensayo de balance y perspectivas". Persona y Sociedad, Universidad Alberto Hurtado, Vol. XVIII, N², 213-236, 2004, p. 231.

${ }^{26}$ Por ejemplo, a través de reformas a la ley de Seguridad, del Código de Justicia Militar, la Ley de control de armas , y por último a través de la introducción de una Ley antiterrorista. HERNÁNDEZ, "El Derecho Penal", cit. nota $n^{0} 25$.

27 JIMÉNEZ, María Angélica y SANTOS, Tamara, “¿Qué hacer con las alternativas a la prisión?, Nova Criminis, Facultad de Ciencias Jurídicas y Sociales de la Universidad Central de Chile, No 1, 157-240, 2010, p. 158.

${ }^{28}$ JIMÉNEZ/SANTOS, “Qué hacer”, cit. nota, nº 27, p.160.

${ }^{29}$ JIMÉNEZ/SANTOS, “Qué hacer”, cit. nota, n 27, p.162.

30 HOFER, María Eugenia, "Medidas alternativas a la reclusión en Chile", Conceptos, Fundación Paz Ciudadana, $\mathrm{N}^{\circ} 4,2008$, p. 3.
} 
defensistas. Sin perjuicio de lo anterior, en general dichas políticas no fueron implementadas de manera adecuada, al no dotarlas con el presupuesto necesario para ejecutarlas, lo que se observa de manera clara en la ilusoria puesta en marcha de la Ley $\mathrm{N}^{\mathrm{o}} 11.625$ ó en la precaria implementación de la Ley $\mathrm{N}^{\mathrm{o}} 18.216$. A eso se agregan las constantes críticas a un sistema penitenciario anacrónico y en el cual los ideales resocializadores del positivismo no se vieron materializados ni en la infraestructura ni en las prácticas de los operadores.

A lo anterior se deben sumar las peculiaridades de las políticas criminales en el contexto latinoamericano, en la medida que éstas generalmente se vieron entremezcladas con las iniciativas tendientes a reprimir a los disidentes de los regímenes de la época. Esto, a su vez, significó que las nuevas tendencias criminológicas comparadas no tuvieron mayor influencia, salvo calificadas excepciones, sino también que todo el "colapso de la fe correccionalista" y la noción de que "nada funciona" con su total "desmoralización", que erosionó la credibilidad de las instituciones clave en el control del delito, ${ }^{31}$ finalmente no tuvieron impacto en el sentido común de los actores políticos ni tampoco en el quehacer de los pocos expertos institucionales de ese tiempo.

Sin embargo, como se verá en la sección siguiente, la mayoría de las políticas criminales que se observan en la actualidad, están dotadas de un contenido punitivo, lo que nos lleva a cuestionarnos por qué se genera tal reacción si el supuesto desmoronamiento del correccionalismo y de los ideales de resocialización nunca nos alcanzó. Tal vez, la respuesta se encuentra en el hecho de que no podemos perder algo que nunca tuvimos, de manera que no podemos perder los objetivos correccionales y de resocialización que en realidad nunca implementamos, como se ha explicado anteriormente. En ese sentido, las políticas públicas en materia delictual, adoptadas en los últimos veinte años, pueden basarse más en nuestras tradiciones políticas que siempre han visto el endurecimiento de las penas como una herramienta apropiada de control del crimen. Por otra parte, como se verá en la siguiente sección, se pueden observar otras circunstancias que han influido en gran medida en el desarrollo de las políticas criminales, que puede valer la pena tener en cuenta.

\subsection{Las políticas criminales de las últimas dos décadas.}

Al comienzo de la década de los 90 o "período de transición”, una de las principales tareas del gobierno de la Concertación ${ }^{32}$ consistió como señala Boeninger, en "lograr el rápido y completo retorno de las Fuerzas Armadas a sus cuarteles, y su reinserción en el orden político democrático como instituciones esencialmente obedientes, apolíticas, profesionales, jerárquicas y disciplinadas". 33

${ }_{31}^{31}$ GARLAND, David. La cultura del Control, Barcelona: Gédisa, 2001, p. 119.

${ }^{32}$ La Concertación se formó en 1988 y aglutinó más de quince partidos y movimientos chilenos en un esfuerzo conjunto para ganar el plebiscito de la época. Su composición original ha cambiado y actualmente está integrada por cuatro partidos: la Democracia Cristiana (PDC), el Partido Socialista (PS), el Partido por la Democracia (PPD) y el Partido Radical Socialdemócrata (PRSD). Gobernaron el país, desde 1989, en cuatro gobiernos consecutivos con los siguientes presidentes: Patricio Aylwin, PDC (1990-1994); Eduardo Frei, PDC (1994-2000); Ricardo Lagos, PS-PPD (2000-2006) y Michelle Bachelet, PS (2006-2010).

${ }^{33}$ BOENINGER, Enrique, Democracia en Chile: Lecciones para la gobernabilidad. Santiago: Andrés Bello, 1998, p. 390. Cit.: DAMMERT, Lucía, "From Public Security to Citizen Security in Chile" en: BAILEY, 
Polit. crim. Vol. 7, № 13 (Julio 2012), Art. 3, pp. 94 - 146.

[http://www.politicacriminal.cl/Vol_07/n_13/Vol7N13A3.pdf]

El terrorismo y los constantes cuestionamientos en materia de derechos humanos, constituyeron dos problemas centrales para el gobierno. ${ }^{34}$ Con respecto al primero, aunque el gobierno recientemente elegido estaba convencido de que la violencia de los grupos extremos iba a desaparecer automáticamente después del retorno de la democracia, esto en la práctica no ocurrió. Considerando lo anterior, el gobierno adoptó una reacción represiva silenciosa así como una estrategia en orden a reducir las sentencias y organizar la libertad anticipada de aquellas personas recluidas por sus creencias y no por actividades violentas. ${ }^{35}$ En relación a los derechos humanos, el gobierno tuvo que negociar con las fuerzas armadas de manera que su poder tradicional se mantuviera, mientras se buscaba limitar su influencia en las materias de seguridad. ${ }^{36}$ Teniendo en cuenta esos antecedentes, Dammert argumenta que durante este período, se aprobaron tres grupos de leyes en materia político criminal: unas que buscaban dotar a instituciones recientemente creadas de competencias en materia de seguridad ciudadana (v. gr. Ley N¹9.212, que creó la Dirección de Seguridad Pública e Informaciones); otras que se enfocaron en materia policial, incluyendo recursos humanos y operativos, así como la reconfiguración de su rol (v. gr. Ley No19.006 que amplió la planta de Carabineros); y un tercer grupo que buscó reducir las penas y otorgar beneficios a los prisioneros políticos (v. gr. Ley $\mathrm{N}^{\mathrm{0}} 19.055$, que estableció indultos, amnistía y libertad condicional para este grupo). ${ }^{37}$

Además de estas medidas, se realizaron también algunas reformas menores a la justicia penal, buscando adaptar el marco legal a los requerimientos internacionales, así como a los tratados internacionales sobre los derechos humanos que fueron incorporados a la legislación chilena. Por consiguiente, en ese tiempo, se introdujeron algunas reformas menores e irregulares a la justicia procesal, tales como la Ley $\mathrm{N}^{\mathrm{0}} 19.047$ que estableció entre otras modificaciones, el derecho de los imputados a la libertad provisional mientras se encuentren bajo investigación, excepto en casos calificados; o la obligación del juez de indagar si éstos han sido sometidos a torturas o amenazas.

Como consecuencia de la adopción de algunas de las medidas antes descritas y otras, como la concesión de beneficios intrapenitenciarios, ${ }^{38}$ entre 1989 y 1992, el total de la población carcelaria disminuyó en casi 4,000 internos. ${ }^{39}$

Al mismo tiempo, en este período, comenzó un debate en relación a la necesidad de contar con una reforma integral de la justicia procesal, especialmente en materia penal, cuyo cuerpo orgánico databa de 1906 y que establecía un sistema inquisitivo totalmente decimonónico. Fue así, como la redacción del nuevo Código Procesal Penal, se confió a algunos expertos, y su discusión legislativa se inició a mediados de los años 90, basada

John y DAMMERT, Lucía (Eds), Public Security and Police Reform in the Americas, Pittsburgh: University of Pittsburgh Press, 2006, p. 62- 63. La traducción es de la autora.

${ }^{34}$ DAMMERT, "From Public Security", cit. nota no 33, p.63.

${ }^{35}$ DAMMERT, "From Public Security", cit. nota no 33, p.63.

${ }^{36}$ DAMMERT, "From Public Security”, cit. nota no 33, p.63.

${ }^{37}$ DAMMERT, "From Public Security", cit. nota no 33, p.63.

${ }^{38}$ DAMMERT, Lucía, El sistema penitenciario en Chile: Desafios para el nuevo modelo público-privado, artículo preparado para ser presentado en la reunión anual de Asociación de Estudios Latino Americanos, San Juan, Puerto Rico, 15 al 18 de Marzo, 2006, p.2.

${ }^{39}$ Ver en Anexo, Tabla N ${ }^{\circ} 1$ y Gráfico $N^{\circ} 1$. 


\section{MORALES, Ana María. "La política criminal contemporánea: Influencia en Chile del discurso de la ley y el orden".}

ahora en un modelo adversarial. Lo importante de este proceso, es que en él convergió una alianza de intereses. Así, para el gobierno la reforma significaba implementar un modelo respetuoso de las garantías procesales de los imputados, mientras que para la oposición implicaba generar una persecución penal más efectiva. ${ }^{40}$ Esta reforma finalmente se implementaría bajo el gobierno del Presidente Ricardo Lagos.

Este escenario comenzó a cambiar a mediados de los años 90, a medida que la delincuencia comenzó ser abordada como un tema político, una situación que encontró al país con sistemas de información poco sistemáticos y sofisticados. ${ }^{41}$ En efecto, la información sobre las denuncias registradas era publicada por la institución policial "sin mayor revisión o análisis por parte del gobierno o de la sociedad civil". 42 A pesar de eso, la información disponible en ese tiempo ${ }^{43}$ muestra que, a comienzos de los años 90, las denuncias de delitos contra la propiedad se elevaron y luego disminuyeron levemente a mediados de la misma década, mientras que las denuncias de delitos cometidos contra las personas, disminuyeron consistentemente desde el período desde 1985 hasta 1995, cuando alcanzaron su punto más bajo. ${ }^{44}$

En este nuevo contexto político, se comenzaron a aprobar leyes tendientes a endurecer la respuesta sancionatoria frente a determinados tipos penales, como se observa en la promulgación de la Ley N 19.413 de 1995, que reguló de manera autónoma el delito de receptación, la Ley №19.449 de 1996, que estableció normas especiales en relación al juzgamiento del robo con fuerza en las cosas, el hurto y el robo con intimidación, o la Ley $\mathrm{N}^{\circ} 19.617$ que modificó el delito de violación y reguló el estupro, los abusos sexuales y la corrupción de menores.

Hacia finales de década de 1990 y, especialmente en la campaña presidencial previa a la elección presidencial del año 2000, la delincuencia y las formas de enfrentarla, comenzaron a monopolizar la agenda política. Fue así como en los respectivos programas de gobierno, se pudieron observar posturas tendientes a endurecer la respuesta político criminal. ${ }^{45}$ Así

\footnotetext{
${ }^{40}$ MATUS, “La Doctrina penal”, cit. nota $n^{\circ} 12$.

${ }^{41}$ LÓPEZ, Eduardo, "Reflexiones acerca de la seguridad ciudadana en Chile: visiones y propuestas para el diseño de una política", Serie Políticas Sociales, Santiago, CEPAL, No 44, 2000. Cit.: DAMMERT, Lucía, "Violencia criminal y seguridad ciudadana en Chile", Serie Políticas Sociales, Santiago: Naciones Unidas, FLACSO, 2005, p. 7.

${ }^{42}$ DAMMERT, "Violencia criminal", cit. nota $n^{\circ} 41$, p. 7.

${ }^{43}$ Esta información está basada en la información pública contenida en un informe del Foro de Expertos en Seguridad Ciudadana (2004), convocado por el Ministerio del Interior para obtener una propuesta para el diseño de políticas de prevención delictual, basado en información proporcionada por la policía, que está compuesta por los denominados "delitos de mayor connotación social", construida por la sumatoria de las denuncias de algunos delitos contra la propiedad (robo con fuerza y hurto) y de algunos delitos contra las personas (robo con violencia, lesiones, homicidio y violación); una clasificación tradicionalmente usada por el Ministerio del Interior para propósitos estadísticos.

${ }^{44}$ Ver en Anexo gráfico No2.

${ }^{45}$ En particular, se analizarán las propuestas efectuadas en esta arena por aquellos candidatos que agrupaban las mayores preferencias, excluyéndose ex professo, el análisis de las propuestas efectuadas por candidatos con menor representación popular, por razones de extensión del documento.
} 
Polit. crim. Vol. 7, № 13 (Julio 2012), Art. 3, pp. 94 - 146.

[http://www.politicacriminal.cl/Vol_07/n_13/Vol7N13A3.pdf]

por ejemplo, el candidato presidencial de la Alianza por Chile ${ }^{46}$, Joaquín Lavín, en materia de seguridad ciudadana, entre otras propuestas, sentenció la necesidad de

"endurecer la legislación relacionada con la materia restringiendo la libertad provisional, y terminar con el indulto presidencial, estableciendo en su reemplazo un real presidio perpetuo. Además, propuso restringir los beneficios carcelarios a quienes reincidan en delitos graves y ubicar las cárceles en lugares aislados". 4748

Considerando que éste era el talón de Aquiles del candidato de la Concertación, si bien en su programa de gobierno, enfatizó el ámbito social de la prevención y combate a la delincuencia, en esta área planteó la necesidad de promover la

"revisión integral de la legislación penal por la coherencia del sistema de penas y su efectivo cumplimiento (...) y dotaremos a los Tribunales de justica de los instrumentos legales que permitan discriminar entre el gran delito de narcotráfico y el delito de microtráfico". 49

Este énfasis político en el endurecimiento de las medidas de control del delito de finales de los años 90 y principios de 2000, se ve acompañado de un alza en las estadísticas delictuales. Así, aunque su sistematización mejoró en esa época, considerando que el Ministerio del Interior había implementado un sistema de información que fusionaba los datos registrados por ambas fuerzas policiales, convirtiéndose en "fuente oficial de información sobre el accionar delictual en el país", 50 aún recaía en una sola fuente, esto es, en la información sobre las denuncias de ambas policías. ${ }^{51}$ En efecto, la información disponible muestra que, a mediados de la década de 1990, los delitos denunciados habían llegado al punto más bajo de la década y luego empezaron a aumentar, especialmente en relación a los delitos contra la propiedad. ${ }^{52}$

Aun, cuando el candidato de la Concertación ganó finalmente la elección, en un estrecho balotaje, durante su mandato efectivamente implementó algunas de las duras medidas que al final de su campaña prometió adoptar, aunque también lideró reformas de corte liberal, como el lanzamiento de un nuevo sistema procesal penal. Esta reforma, con el principio de inocencia como eje central de su estructura, fue sin duda la medida política criminal más importante de todo su gobierno, siendo catalogada "por las autoridades y sectores importantes de la sociedad civil como "la reforma del siglo",, enfatizando con ello la

\footnotetext{
${ }^{46}$ Coalición política de centroderecha integrada por dos partidos políticos: la Unión Demócrata Independiente (UDI), gremialistas, y Renovación Nacional (RN).

${ }^{47}$ DÁVILA, Mireya, Seguridad Ciudadana: Actores y Discusión, Santiago: FLACSO-Chile, 2000 , p. 67.

${ }^{48}$ Plan de gobierno de Joaquín Lavín. Disponible en: http://www.archivochile.com/Partidos burguesia/udi/de/PBdeudi0006.pdf

49 Plan de gobierno de Ricardo Lagos, p. 22. Disponible en: http:/www.archivochile.com/Gobiernos/gob rlagos/de/GOBdelagos0002.pdf

${ }^{50}$ DAMMERT, "Violencia criminal", cit. nota $\mathrm{n}^{\circ} 41, \mathrm{p} .7$.

51 Este sistema se mantuvo, hasta el lanzamiento, el año 2003, de la primera encuesta nacional de victimización denominada "Encuesta Nacional Urbana de Seguridad Ciudadana" (ENUSC).

${ }^{52}$ Ver en Anexo gráfico $\mathrm{N}^{\circ} 2$.
} 
MORALES, Ana María. "La política criminal contemporánea: Influencia en Chile del discurso de la ley y el orden".

relevancia que este cambio ha tenido para nuestro sistema legal y para su arquitectura institucional en general. ${ }^{53}$

Asimismo, a finales del año 2000, en un nuevo intento codificador, el Ministro de Justicia de la época convocó un "Foro Penal", al que fueron convocados los principales profesores y abogados especialistas en derecho penal, con el objeto de discutir un nuevo Código Penal. Dicha instancia, si bien sufrió una serie de deserciones, considerando las fricciones internas del debate, entregó a fines de 2005 un ante proyecto. A juicio de uno de sus integrantes, los objetivos del foro fueron en realidad modestos, y "con seguridad, no coincidentes con la idea de una verdadera recodificación", siendo más bien un "remozamiento general del viejo código". 54 En esa línea, como señala otro forista, al momento de redactarse las propuestas normativas, se realizó más bien "un trabajo de revisión del Código Penal vigente y de las leyes penales especiales, antes que la adopción de modelos completos extranjeros". ${ }^{55}$ En ese contexto, como señala Fernández, se contempló un código de estructura político criminal liberal, sustentado en los principios de proporcionalidad y culpabilidad, en la cual se depuraron aquellas disposiciones anacrónicas y superfluas de la regulación actual. Además, se incluyó gran parte de las figuras penales que en la actualidad se encuentran reguladas en leyes especiales, y en consonancia con los códigos modernos, se incluyó la protección de bienes jurídicos o intereses como el medio ambiente $\mathrm{y}$ el orden socioeconómico. ${ }^{56}$ Como puede observarse, este intento codificador no tuvo pretensiones trasformadoras, si no más bien fue un trabajo de depuración y actualización. Sin embargo, aun considerando sus modestas pretensiones, el anteproyecto perdió apoyo de algunos de sus integrantes, y lo principal es que en el sucesivo gobierno, no se efectuaron esfuerzos políticos tendientes a materializar su discusión ante el Congreso Nacional, lo que de cierta forma parece explicarse por una agenda político criminal que apostaba por énfasis distintos, como se verá más adelante.

Durante este período, el poder ejecutivo también lideró la discusión parlamentaria relativa al establecimiento de un juzgamiento especial para adolescentes infractores de la ley penal, de entre 14 y 17 años de edad. Este sistema se encuentra inspirado en las directrices de la convención de los Derechos del Niño y en particular en su "interés superior", y a su vez toma como base el modelo de "justicia" o de "responsabilidad" 57, y donde las medidas y sanciones debieran ser dotadas de contenidos reintegrativos y reparatorios, con énfasis en la prevención especial positiva. Sin perjuicio de lo anterior, esta reforma se puso en marcha finalmente el año 2007, con algunos profundos cambios a su conceptualización original, y con serios problemas de implementación que impidieron la materialización de las aspiraciones antes señaladas.

\footnotetext{
${ }^{53}$ DUCE, Mauricio, "Diez años de Reforma Procesal Penal en Chile: Apuntes sobre su desarrollo, logros y desafíos", en "A diez años de la Reforma Procesal Penal: Los desafios del nuevo sistema", Santiago: Ministerio de Justicia, 2010, p. 191.

${ }^{54}$ HERNÁNDEZ, "El Derecho Penal", cit. nota no 25, p. 234.

${ }^{55}$ MATUS, "La Doctrina penal”, cit. nota $n^{\circ} 12$, p. 194.

56 FERNÁNDEZ, José Ángel, "El Nuevo código penal: una lucha por el discurso de la criminalidad”, Política Criminal, n¹, 2006, A5, pp. 1-30.

${ }^{57}$ KEMELMAJER, Aída, Justicia Restaurativa, Buenos Aires: Rubinzal-Culzoni, 2004, p. 62.
} 
Polit. crim. Vol. 7, № 13 (Julio 2012), Art. 3, pp. 94 - 146.

[http://www.politicacriminal.cl/Vol_07/n_13/Vol7N13A3.pdf]

Sin embargo, la variante punitiva se hizo más fuerte, como puede observarse en el contenido de las leyes en materia de seguridad ciudadana, aprobadas durante el período del Presidente Lagos. Así, se puede observar que el nuevo Código Procesal Penal vigente desde el año 2000, durante su mandato fue modificado por lo menos seis oportunidades, donde tres de estas modificaciones (v.gr. Leyes $\mathrm{N}^{\mathrm{o}} 19.789$, 19.942 y 20.074) apuntaron hacia una ampliación de las atribuciones de la policía en áreas preventivas tales como el control de identidad, prolongando la duración legal de este proceso, o introduciendo modificaciones en la esfera de la detención y la citación en casos de flagrancia, aumentando las hipótesis que las hacen procedentes, y autorizando el registro de vestimentas, equipajes y vehículos en caso de citaciones por la comisión de faltas penales, entre otras modificaciones. En la misma línea, la última de estas leyes (Ley N²0.074) intensificó las causales de procedencia de la prisión preventiva en relación a la necesidad de cautela, incorporando consideraciones relativas al "peligro para la sociedad" para determinar su aplicación, lo que finalmente afectó la presunción de inocencia y la lógica de proporcionalidad que había inspirado, con entusiasmo, el diseño de las medidas cautelares en el contexto de la reforma procesal penal.

Al respecto, vale la pena mencionar que, al menos, dos de estas modificaciones nacieron en el seno de un "comité de expertos" -formado principalmente por especialistas chilenos-, convocado por el Ministerio de Justicia de la época, con el propósito de recibir sugerencias para el mejoramiento de la nueva legislación; por lo tanto, estas modificaciones fueron producto de un debate académico en el cual también se escuchó el punto de vista de los operadores del nuevo proceso penal. Uno de los principales problemas en relación a la generación de estas propuestas, es que -considerando su reciente implementación-, la evidencia empírica en que se apoyaron fue escasa. Por lo tanto, para justificar la necesariedad de las mismas, se recurrió a argumentos vinculados con la "inseguridad subjetiva" o temor, que aparentemente sentían los habitantes. ${ }^{58}$ Por otra parte, aunque las denuncias de los delitos de mayor connotación social aumentaron dramáticamente desde fines de los años $90 \mathrm{y}$, en especial, desde el 2000, ${ }^{59}$ este aumento era esperable por el gobierno, considerando que la implementación de la reforma procesal penal probablemente tendría incidencia en los niveles de delitos no registrados o cifra negra, en la medida que "la confianza en el sistema de justicia criminal aumentó y la percepción de ineficiencia del sistema judicial declinó levemente". ${ }^{\circ}$

Durante ese tiempo, se buscaron otras modificaciones legales con el propósito de aumentar las herramientas preventivas de la policía y el Ministerio Público en la investigación de tipos penales específicos, como la pornografía infantil (Ley $\mathrm{N}^{\mathrm{o}} \mathrm{N}^{\mathrm{o}} 19.927$ ) o aquéllos relacionados con el tráfico de drogas (Ley $\mathrm{N}^{\circ} 20.000$ ). En el caso de la primera, esta nueva reforma "producto de la conmoción social causada por la revelación de una serie de casos

\footnotetext{
${ }^{58}$ Esto fue observado por Horvitz y López en el año 2003, cuando se promulgó la primera de estas modificaciones. HORVITZ, María Inés y LÓPEZ, Julián, Derecho Procesal Penal, Tomo I, Santiago: Editorial Jurídica, 2003, p. 594. Sin embargo, este análisis también es replicable a la última legislación mencionada, como se desprende del mensaje que se envió para someter a discusión del Congreso Nacional el proyecto de ley, que posteriormente se concretaría en la Ley $\mathrm{N}^{\circ} 20.074$ (Mensaje $\mathrm{N}^{\circ} 440-350$ ).

${ }^{59}$ Ver en Anexo gráfico No2.

${ }^{60}$ DAMMERT, "From Public Security”, cit. nota no 33, p. 9.
} 


\section{MORALES, Ana María. "La política criminal contemporánea:} Influencia en Chile del discurso de la ley y el orden".

de abusos sexuales perpetrados contra menores", 61 significó que los párrafos dedicados a consagrar los tipos penales relativos a la libertad y la indemnidad sexual fueran nuevamente modificados, sufriendo un aumento de penas en algunos casos y la creación de nuevos tipos penales en otros, lo que ha acarreado diversos problemas interpretativos. ${ }^{62}$ Por otro lado, en relación a la segunda de estas normativas, es necesario recordar que dicha legislación constituyó una de las propuestas de plan de gobierno, y una de sus principales novedades apuntó a la incorporación en su artículo $4^{\circ}$ de la figura del microtráfico, que como sostiene Matus se trata de "una figura cuyo propósito declarado es ofrecer a los tribunales la posibilidad de imponer una pena inferior a los dealers callejeros", 63 que hasta antes de esta legislación o eran condenados bajo la figura de tráfico o no se les imponía pena alguna. Finalmente, otra regulación importante de la época la encontramos en la Ley Nº19.950, que introdujo modificaciones al delito de hurto, bajo la idea de facilitar el juzgamiento de este tipo penal, contemplando el denominado "hurto-falta". Como señala Oliver, esta modificación se inserta dentro de una tendencia propia de los tiempos actuales de la política criminal, cual es el adelantamiento de la barrera de protección penal de los bienes jurídicos. De esta forma, se decide penalizar etapas ejecutivas anteriores a la consumación, en una materia que "siempre ha sido considerada como criminalidad de bagatela", ${ }^{64}$ generando una "preocupante tendencia a una especie de administrativización del Derecho Penal". 65

En la elección presidencial de 2005, el planteamiento de diversas estrategias asociadas al control del delito, continuó siendo uno de los ejes de la campaña, una situación que fue apoyada por estudios de opinión que mostraron que los problemas de mayor preocupación para la gente eran -en orden descendente de importancia- la delincuencia (47\%), el empleo (44\%), la salud (42\%), la pobreza (35\%), los sueldos $(29 \%)$, la educación $(28 \%)$, y las drogas $(16 \%)$, junto a un número de problemas que recibieron menor atención. ${ }^{66}$ En ese contexto, la mayoría de los candidatos de esa elección presidencial, se enfrascaron en una suerte de "competencia de dureza", presentando consignas recicladas y algunas nuevas medidas populistas. ${ }^{67}$ En esa elección, la alianza estuvo representada por dos candidatos. El primero, Joaquín Lavín, apelaba una vez más a las estrategias que casi lo llevaron a la presidencia la vez anterior. Algunas de las medidas que propuso en su nuevo plan de gobierno apuntaron a abordar a los sujetos reincidentes a través de la estrategia de "la

\footnotetext{
${ }^{61}$ FERNÁNDEZ, José Ángel, “Los delitos de violación y estupro del artículo 365 bis del Código Penal: Una racionalización desde el mandato de Lex stricta y el principio de lesividad. Especial referencia a la introducción de dedos u otras partes del cuerpo", Revista Ius et Praxis v.13 n.2 105-135, Talca, 2007, p. 106.

62 Sobre el particular, véase entre otros: FERNÁNDEZ, "Los delitos de violación", cit. nota $\mathrm{n}^{\circ}$ 61; RAMÍREZ, María Cecilia. "Delitos de abuso sexual: actos de significación sexual y de relevancia". Política Criminal, $\mathrm{n}^{\circ}$ 3, 2007. A4. p. 1-13.

${ }^{63}$ MATUS, Jean Pierre, "Informe acerca de algunos aspectos que se han mostrado problemáticos en la aplicación práctica de la Ley No20.000”, Revista Ius et Praxis v.11 n.2 333- 350, Talca, 2005, s/p.

${ }^{64}$ OLIVER, Guillermo, "Análisis crítico de las últimas modificaciones legales en materia de hurto-falta". Revista de Derecho, (Valparaíso), vol. 1, núm. XXVI, 2005, pp. 295-307, p. 299.

${ }^{65}$ CARNEVALI, Raúl, "Criterios para la punición de la tentativa en el delito de hurto a establecimientos de autoservicio. Consideraciones político-criminales relativas a la pequeña delincuencia patrimonial”. Política Criminal, nº 1, 2006. A2, p. 1-17, p. 5.

${ }^{66}$ Estudio Nacional de opinión pública n²1, Centro de Estudios Públicos, p.58.

${ }^{67}$ Al igual que en el análisis de las elecciones de 1999, en particular se analizarán las propuestas efectuadas en esta arena por aquellos candidatos que agrupaban las mayores preferencias, excluyéndose ex professo, el análisis de aquellas propuestas efectuadas por candidatos con menor representación popular.
} 
Polit. crim. Vol. 7, № 13 (Julio 2012), Art. 3, pp. 94 - 146.

[http://www.politicacriminal.cl/Vol_07/n_13/Vol7N13A3.pdf]

tercera es la vencida", tomada de la experiencia del Estado de California en la ley denominada comúnmente "Three strikes and you're out" (Tres strikes y quedas fuera). Como planteó en su programa de gobierno

“el delincuente que por tercera vez comete un delito grave, tendrá una pena mínima de 15 años, sin acceso a ningún beneficio. La experiencia ha demostrado ser exitosa en Estados Unidos, donde 3 de los 5 estados con mayor reducción del delitos tienen dicha legislación". 68

Asimismo, en materia penitenciaria, entre otras medidas sostuvo

"A fin de garantizar el aislamiento de reclusos peligrosos, asegurando la posibilidad de rehabilitación a través del trabajo, se propone la habilitación de una cárcel-isla. A ella se destinarían los reclusos más peligrosos, que hayan cometido delitos violentos; específicamente condenados por homicidio, violación, narcotráfico y asaltos". 69

Por otro lado, el otro candidato de la Alianza, Sebastián Piñera -que finalmente pasó a la segunda vuelta con la candidata de la Concertación- argumentó en esta materia, la necesidad de

“combatir la reincidencia y sacar de las calles a los delincuentes más peligrosos, es preciso aumentar la pena de los delincuentes reincidentes, que son los que hacen de las conductas delictuales una verdadera "profesión", con gran daño a la seguridad ciudadana, lo que contribuye decididamente a crear una sensación legítima de inseguridad en la gente honesta, que es la inmensa mayoría del país. Por eso es el reincidente quien concentra la atención en esta propuesta, destinada a disuadirlo de delinquir por segunda o tercera vez. Nuestra proposición tiene el objetivo central de modificar la estructura de imposición de penas en caso de reincidencias de las personas que son autores de los delitos más graves (delitos sexuales, robo, hurto y secuestros de personas), estableciendo nuevos mecanismos que en la práctica aumentarán progresivamente el castigo penal para los delincuentes que reincidan en estos tipos delictuales por segunda y tercera vez («la tercera es la vencida»)".70

En este contexto, la candidata Michelle Bachelet no se quedó atrás en sus propuestas en materia de control del delito, comprometiendo la creación de un Ministerio de Seguridad Ciudadana, que sería institucionalmente responsable de ambas fuerzas policiales, junto con algunas propuestas compartidas con los programas de gobierno de los otros candidatos, tales como el generar

"un sistema de justicia severo con aquellos que hacen del delito una profesión. Legislaremos para que exista un estricto control sobre quienes salen en libertad provisional o condicional, o acceden a beneficios carcelarios. Ninguna persona que delinca al amparo de estos beneficios podrá acceder a ellos nuevamente. Pondremos

\footnotetext{
${ }^{68}$ Plan de gobierno, p.15. Disponible en http://www.emol.com/especiales/_elecciones_2005/descargas/progama_lavin.pdf

${ }^{69}$ Plan de gobierno, cit. nota $\mathrm{n}^{\mathrm{o}} 68, \mathrm{p} .15$.

${ }^{70}$ Plan de gobierno, pp.66-67. Disponible en http://www.emol.com/especiales/_elecciones_2005/descargas/programa_pinera.pdf
} 


\section{MORALES, Ana María. "La política criminal contemporánea: Influencia en Chile del discurso de la ley y el orden".}

mayores obstáculos a los delincuentes reincidentes que quieran obtener libertad condicional.

Proponemos, además, que para los casos de reincidencia en delitos graves el físcal se vea obligado a solicitar la medida cautelar de privación de libertad". ${ }^{71}$

Durante el gobierno de la Presidenta Bachelet, algunas de estas propuestas efectivamente se tradujeron en la presentación de proyectos de ley. La estructura del nuevo ministerio fue confiado a un grupo de expertos, y en menos de tres meses desde la iniciación de su mandato, se envió al Congreso un proyecto de ley que establecía un

"nuevo Ministerio de Seguridad Pública tendrá que ser el eje institucional capaz de definir la política de prevención y control de la delincuencia, coordinando a los entes públicos cuyo actuar incide directamente en los factores que determinan la seguridad y abriendo canales de participación para las organizaciones académicas y las de la sociedad civil. $^{72}$

Luego de un largo debate y de la presentación de una serie de indicaciones, este proyecto de ley derivó en la creación de la actual Subsecretaría de Prevención del Delito, mediante la promulgación de la Ley $\mathrm{N}^{\circ} 20.502$ de 2011. Considerando su reciente creación, no es posible evaluar su impacto en término de las políticas criminales. Sin embargo, la experiencia comparada en esta materia ha demostrado lo desaconsejable de regular la prevención y control del delito en la misma sede del órgano encargado de ostentar el poder político, considerando lo volátil de estas temáticas en tiempos electorales. De ahí que hubiera sido aconsejable la creación de una institucionalidad de rango ministerial separada, como se establecía originalmente en el proyecto de ley que inspiró su creación.

Por otro lado, también durante este gobierno, se presentó nuevamente ante el Congreso Nacional un proyecto de ley de modificación del código procesal penal, que buscaba abordar algunas de las propuestas del programa de gobierno, antes mencionadas. Sin embargo, esta vez, no se consultó ni a expertos ni a académicos, y el mensaje del proyecto, como en otras oportunidades, se apoyó en el aumento de la inseguridad o temor de la población. Así, como lo planteó el mensaje

"la ciudadanía da señales de temor subjetivo ante el actuar de la delincuencia, que hace necesario introducir mejoras en el sistema, destinadas a reprimir con mayor energía al delito y disminuir esa sensación de temor". 73

Al respecto, es necesario tener presente, que en el mismo mes en que se estaba preparando el citado proyecto de ley, el Ministerio del Interior publicó los resultados de su segunda encuesta de victimización, llevada a cabo en el 2005, que mostró una reducción en la

\footnotetext{
${ }^{71}$ Plan de gobierno, p. 65. Disponible en: http://www.emol.com/especiales/ elecciones 2005/descargas/programa Bachelet.pdf

${ }_{72}$ Mensaje No161-354 del proyecto de ley que crea el Ministerio de Seguridad Pública, el Servicio Nacional para la prevención del consumo y tráfico de drogas y modifica diversos cuerpos legales, p. 6.

${ }^{73}$ Mensaje $N^{\circ} 188-354$ del proyecto de ley que modifica el código procesal penal en materia de seguridad ciudadana, y refuerza las atribuciones preventivas de la policía, p. 1.
} 
victimización general de 4,7\%, en comparación con el años $2003,{ }^{74}$ y sólo un leve aumento en la inseguridad subjetiva en el mismo período de $0.8 \%{ }^{75}$

El citado proyecto, luego de un intenso debate en el Congreso, fue aprobado el año 2008 bajo la Ley No20.253, comúnmente denominada "agenda corta antidelincuencia". Una de las principales modificaciones contenidas en este cuerpo legal, dice relación con la reinterpretación del concepto de reincidencia contemplado en el Código Penal, al sustituir el vocablo "castigado" por "condenado". Mediante esta modificación se pretendió incluir dentro de este concepto, no sólo a aquellos sujetos que hubieren cumplido efectivamente una pena, sino que también al que hubiere sido condenado, independientemente si le dio cumplimiento efectivo o no, recogiendo también por esta regla al que hubiere sido condenado a una medida alternativa de aquéllas contempladas en la Ley $\mathrm{N}^{\mathrm{o}} 18.216$.

Otra de las modificaciones introducidas por esta ley, importantes de mencionar, dice relación con el procedimiento preventivo de control de identidad. De esta forma, mediante la modificación al artículo 85 del Código Procesal Penal, se extendió nuevamente el plazo legal para su ejercicio, de 6 a 8 horas, junto con establecer la posibilidad de cotejar la existencia de ordenes de detención durante este procedimiento. Además, se estableció mediante una cuestionable técnica legislativa un nuevo indicio que autoriza su práctica, relativo al que se "se encapuche o emboce para ocultar, dificultar o disimular su identidad".

En la misma línea, esta ley contempló algunas normas particulares en relación al régimen de medidas cautelares. En primer lugar, se modificó el artículo 140 en lo relativo a los fundamentos de la necesidad de cautela, estableciendo dentro sus causales de procedencia explícitamente el peligro de fuga. Con esta reforma, se buscó distanciar el concepto de "peligro para la sociedad" del "peligro de fuga", criterio hasta entonces considerado por parte de la Jurisprudencia, como la única interpretación acorde con la legislación internacional vigente sobre la materia. Por otro lado, nuevamente en relación al concepto de "peligro para la sociedad", la ley estableció dentro las consideraciones que deberá observar el juez en este supuesto, el que la pena en abstracto establecida para el delito fuere una de crimen. Finalmente, para aquellos sujetos que hubieren cometido algunos de los delitos calificados por la ley como "serios": secuestro, sustracción de menor, violación, violación de menor de 14 años, abuso sexual agravado, parricidio, homicidio calificado y simple, robos calificados, robo con violencia o intimidación, robo por sorpresa, robo con fuerza en las cosas, y aquéllos contenidos en la Ley $\mathrm{N}^{\circ} 20.000$ de drogas que tengan asignada pena de crimen; se contempló una excepción estableciendo que el sujeto deberá continuar privado de su libertad, en el evento que hubiere sido revocada la prisión preventiva en primera instancia, a la espera de que la sentencia se encuentre ejecutoriada.

Esta legislación constituye sin duda la más profunda de las modificaciones introducidas al Código Procesal Penal en la década pasada, que claramente vino a socavar las bases garantistas sobre la cual estaba diseñado, especialmente en relación al principio de inocencia y sus derivaciones. Una de las cuestiones que resulta altamente preocupante dice relación con su fundamentación, basada en la inseguridad subjetiva, en circunstancias que

\footnotetext{
${ }^{74}$ Ver en Anexo tabla $\mathrm{N}^{\mathrm{o}} 2$ y gráfico $\mathrm{N}^{\mathrm{o}} 3$

${ }^{75}$ Ver en Anexo tabla $N^{\circ} 3$ y gráfico $N^{\circ} 4$.
} 
MORALES, Ana María. "La política criminal contemporánea:

Influencia en Chile del discurso de la ley y el orden".

paralelamente a su diseño, las encuestas de victimización comenzaron a mostrar por primera vez una disminución, tendencia que en general se ha mantenido. Un segundo aspecto dice relación con los criterios de selección de los tipos penales que pasan a ser objeto de un estatuto especial. En efecto, los delitos señalados no coinciden con los denominados "delitos de mayor connotación social", ni responden a ponderaciones empíricas que sustenten la necesidad de una regulación especial, pareciendo más bien ocultar criterios de incapacitación selectiva. Finalmente, las modificaciones al régimen de la prisión preventiva, como plantea Duce "representó un intento bastante claro por reintroducir un régimen de inexcarcelabilidad como los que existieron hasta antes de las reformas de los años setenta y ochenta en Chile". ${ }^{76}$

Por otro lado, como es fácil deducir, en las elecciones presidenciales de 2009, nuevamente las temáticas vinculadas al control del delito y las políticas públicas necesarias para abordarlas constituyeron en eje esencial, siendo la vertiente punitiva la más invocada por los candidatos. En ellas participaron, entre otros, el candidato de la elección anterior, Sebastián Piñera - que finalmente resultaría electo Presidente- y el ex Presidente Eduardo Frei. De manera de no exceder en el análisis de los planes de gobierno en esta materia, es posible ejemplificar las discusiones en esta arena, en las discrepancias existentes entre los candidatos en relación a la facultad de aplicar indultos de carácter particular, donde el primero de los candidatos reprochó al segundo el haber otorgado durante su mandato un indulto particular a una persona condenada bajo la vigencia de la Ley $\mathrm{N}^{\circ} 19.336$ que sancionaba el tráfico ilícito de estupefacientes y sustancias sicotrópicas, legislación que con posterioridad fue sustituida por la mencionada Ley №20.000.

Como es de esperar, las políticas criminales descritas en los párrafos anteriores, han tenido un impacto importante en relación al crecimiento de población sujeta a control del sistema penitenciario. Como se advierte de las cifras, ${ }^{77}$ desde 1996 comienza a aumentar sostenidamente la población recluida, hasta el año 2005 en que se producen aumentos exponenciales en la población condenada en todos los sistemas, fruto de la instalación de la reforma procesal penal en todo el país. ${ }^{78}$ En efecto, los mayores aumentos se observan entre 2005 y 2010, considerando que la cantidad de personas privadas de su libertad en recintos de Gendarmería varió entre 2000 y 2005, en 10,76\%, mientras que entre 2006 y 2010 experimentó un crecimiento de 44,9\%. En el caso de las medidas alternativas de la Ley $\mathrm{N}^{\circ}$ 18.216 , entre 2000 y 2005 , tuvieron un crecimiento negativo de $17,32 \%$, mientras que entre 2006 y 2010 crecieron explosivamente en $88,61 \%$.

Uno de los aspectos más críticos del marco legislativo político-criminal chileno, es que los cambios radicales que se han propuesto, particularmente aquéllos vinculados a modificaciones al proceso penal, se han apoyado en la inseguridad que declara tener la población, aunque este temor no tiene una correlación con las tasas de criminalidad observadas en la pasada década. En ese sentido, es especialmente preocupante el caso de

\footnotetext{
${ }^{76}$ DUCE, "Diez años de Reforma Procesal Penal”, cit. nota n ${ }^{\circ}$ 53, p. 212.

${ }^{77}$ Ver en Anexo gráfico No5.

${ }^{78}$ Uno de los efectos esperados de la implementación de la Reforma Procesal Penal fue la mayor celeridad de los procesos penales asociados al derecho al juzgamiento en un plazo razonable, de ahí que, en consecuencia, se incrementaran las condenas con su instalación.
} 
Polit. crim. Vol. 7, № 13 (Julio 2012), Art. 3, pp. 94 - 146.

[http://www.politicacriminal.cl/Vol_07/n_13/Vol7N13A3.pdf]

Chile, pues la información disponible muestra que al año 2000, el 78,1\% de los encuestados manifestó tener un nivel alto o medio de temor al delito, cifra que se mantuvo relativamente estable en la última década, con $79 \%$ al $2010 .^{79}$

\section{Tratando de racionalizar la punibilidad.}

Las políticas criminales de corte punitivo, descritas en el capítulo anterior también se pueden observar en otros países. En ese orden de ideas, varios autores han tratado de racionalizar estas características, concentrándose principalmente en el contexto de los Estados Unidos y Gran Bretaña, y ciertamente han proporcionado algunas explicaciones sobresalientes para esta tendencia, tales como la configuración de una sociedad excluyente de Young, o una cultura del control, expuesta por Garland. En el ámbito hispano, también encontramos algunas explicaciones que se acercan bastante a las interpretaciones señaladas, como es el caso del Modelo de la seguridad ciudadana explorado por Diez, y otras que enfatizan en mayor medida las tendencias asociadas al fenómeno de la globalización, como es el caso de la Expansión del derecho penal analizada por Silva. Sin embargo, un rasgo singular de estas interpretaciones es que si bien las primeras se basan en el análisis del contexto anglosajón, y las segundas buscan entender similares tendencias en el ámbito europeo continental, lo cierto es que la mayoría sitúa su análisis político criminal en el contexto asociado al "dilema de las sociedades modernas tardías". ${ }^{8}$

En ese sentido, considerando las tendencias chilenas descritas en el capítulo anterior, surge una justa pregunta: ¿Son adecuadas estas explicaciones para entender la política criminal chilena? Una rápida aproximación puede hacernos responder de manera afirmativa, puesto que varios factores se encuentran ciertamente en la mayoría de los análisis entregados por estos autores, como se verá más adelante. Sin embargo, al enmarcar sus postulados a las realidades locales, como ocurre con el caso de Chile, se puede correr el riesgo de caer en una suerte de dependencia argumentativa, al sugerir que los cambios observados en esos países van necesariamente a ser replicados en otros lugares. Además, de acuerdo a lo señalado por Jones y Newburn, también debemos considerar el peligro de exagerar la evidencia acerca de las diferencias entre países y "pasar por alto algunos importantes elementos de globalización en el cambio de las políticas". 81

Tomando en consideración las prevenciones señalas, en la siguiente sección se analizará las construcciones dadas por autores como los señalados, y se evaluará si son adecuadas para entender la punitividad de las políticas criminales del país.

\subsubsection{El contexto de cambio.}

Jock Young, un connotado criminólogo inglés, describe en su libro La Sociedad "Excluyente" un contraste entre el mundo incluyente -o sociedad canibalística, como él la

\footnotetext{
${ }^{79}$ Ver en Anexo gráfico $\mathrm{N}^{\circ} 6$.

80 FEELEY, Malcom, "Crime, social order, and the rise of neo-Conservative politics", Theoretical Criminology 7 (1) 111-30, 2003, p. 116. La traducción es de la autora.

${ }^{81}$ JONES, Trevor y NEWBURN, Tim, Policy Transfer and Criminal Justice, Maidenhead: Open University Press, 2007, p. 5. La traducción es de la autora.
} 
denomina- de los períodos de post guerra en los años 50 y 60 , y un orden social más excluyente -o sociedad bulímica- de la modernidad tardía observada en el último tercio del siglo veinte hasta nuestros días. En la citada obra, utiliza la descripción de la Edad de Oro como un ejemplo de un período con altas tasas de empleo, trabajos estables, matrimonios y comunidades, que a su vez contrasta con la sociedad posterior, más insegura y dividida. La Edad de Oro fue una manifestación de fuertes lazos sociales, seguridad para las biografías personales y sociales, y también en el campo de las políticas criminales, de un deseo de asimilar a los desviados. A su vez, la modernidad tardía, de acuerdo a este autor, ha generado una inseguridad económica y ontológica, una discontinuidad de las vidas personales y sociales, y una clara tendencia a excluir al desviado. Bajo esta construcción, y siguiendo los postulados básicos del realismo, Young plantea que el incremento de la criminalidad constituye un problema real, que verdaderamente afecta a la gente, lo que es causado por el desplazamiento de las ansiedades hacia las inseguridades económicas, el desarrollo urbano, los temas raciales y otros factores. Aun, cuando Young no nos muestra explícitamente ejemplos de políticas penales de inclusión, se puede inferir de su lectura que naturalmente se está refiriendo a los objetivos de rehabilitación del sistema penal que, a su vez, inspiran el concepto de la sociedad sobre el sujeto desviado. Por el contrario, dos claros ejemplos de manifestaciones públicas de políticas criminales de exclusión las encontramos en las políticas de "tolerancia cero" y lo que él denomina el "experimento carcelario", relacionadas con las actuales políticas de encarcelamiento seguidas en Norteamérica.

Considerando lo anterior, Young sostiene que ejemplos como los señalados, son el resultado de este paso de la Edad de Oro a la modernidad tardía, por lo tanto, se basan más en cambios estructurales y sociales, que en factores aislados.

Si comparamos la construcción señalada con el razonamiento de Garland, relativo al surgimiento de una Cultura del Control, podemos observar que el desarrollado por el criminólogo escocés es más específico, ya que su análisis se basa fundamentalmente en los cambios en el campo del control del delito y la justicia penal, aunque ubica estos cambios en otras causas estructurales, y otras más bien "coyunturales". ${ }^{22}$ En efecto, en la citada obra, este autor busca describir los cambios que concibe como "dramáticos" en el campo del control del delito y la justicia penal, que han ocurrido en Gran Bretaña y los Estados Unidos en los últimos treinta años, ${ }^{83}$ y en ese sentido, su argumento se basa en mostrar cómo las instituciones penales de la modernidad tardía se han adaptado a estos cambios.

Para entender el análisis de Garland, es fundamental entender el concepto de bienestarismo penal. ${ }^{84}$ El punto de partida de esta noción es "la paz y estabilidad del estado de bienestar

\footnotetext{
${ }^{82}$ GARLAND, La cultura, cit. nota $\mathrm{n}^{\mathrm{o}}$ 31, p. 325.

${ }^{83}$ GARLAND, La cultura, cit. nota ${ }^{\circ} 31$, p. 9.

84 Este término debe remontarse a la primera publicación de su trilogía, Punishment and Welfare (1985), donde da su interpretación sobre el aumento del asistencialismo penal, básicamente como una consecuencia de las políticas optimistas y expansivas de la época, que adoptaban una visión del Estado de bienestar. En ese contexto, el concepto de welfarismo o bienestarismo penal es usado por Garland, para referirse a "los dispositivos institucionales que caracterizaron crecientemente el campo desde la década de 1890 hasta la de 1970 y que moldearon el sentido común de generaciones de autoridades políticas, académicos y operadores". GARLAND, La cultura, cit. nota $\mathrm{n}^{\mathrm{o}} 31$, p. 35.
} 
Polit. crim. Vol. 7, № 13 (Julio 2012), Art. 3, pp. 94 - 146.

[http://www.politicacriminal.cl/Vol_07/n_13/Vol7N13A3.pdf]

de postguerra", ${ }^{85}$ que involucraba un "compromiso sin cuestionamientos con la ingeniería social; su confianza en la capacidad del Estado y las posibilidades de la ciencia y su convicción firme de que las condiciones sociales y los individuos delincuentes podían ser reformados a través de las intervenciones de las agencias gubernamentales". ${ }^{86}$

Sin perjuicio de lo descrito, el citado autor reconoce que este objetivo tuvo algunas limitaciones en la práctica, siendo un modelo más equilibrado entre las nociones correccionalistas y las inspiradas en la escuela clásica. Sin embargo, sostiene que a comienzos de los años 70, el discurso rehabilitador fue el dominante entre los encargados de las reformas penales, expertos correccionales y funcionarios de gobierno, un discurso que él cataloga como de "alta modernidad". 87

Junto con las instituciones mencionadas anteriormente, Garland describe que se desarrolló una criminología correccional que veía el delito como un problema social que se manifestaba en la forma de actos delictivos individuales, síntomas de disposiciones subyacentes que se encontraban comúnmente en individuos mal socializados o inadaptados". 88

Una preocupación de esta criminología correccional fue la de estudiar y evaluar el impacto de las diversas intervenciones penales del estado bienestarista, buscando entender "qué funciona" y por qué. ${ }^{89}$ De acuerdo a lo expuesto por Garland, fue en este campo que comenzaron las dudas sobre los motivos correccionales que finalmente terminaron en el desmoronamiento de esta corriente penal, a mediados de los años 70. Aparentemente, un informe del Grupo de Trabajo del Comité de Servicios de Amigos Estadounidenses (Working Party of the American Friends Service Committee) en el cual criticaban el modelo de tratamiento individualizado por ser "teóricamente inconsistente, sistemáticamente discriminatorio en su aplicación e incompatible con algunos de nuestros conceptos más básicos de justicia" ${ }^{90} \mathrm{y}$, más tarde un artículo escrito por Martinson ${ }^{91}$ en el que concluye que "nada funciona" en relación a los esfuerzos de rehabilitación y su influencia en la reincidencia, tuvieron el "efecto dominó" de causar la caída de la fe en el correccionalismo; aunque las opiniones de estos críticos sobre el cambio eran muy diferentes del camino que el sistema penal tomó realmente de ahí en adelante. ${ }^{92}$

Partiendo de la base de este quiebre que se observa a comienzos de los años 70, Garland argumenta, que en los últimos treinta años se ha experimentado un desarrollo dramático en la respuesta social con respecto al delito. Considerando lo anterior, él resume estos cambios en los siguientes rasgos: el declive del ideal rehabilitador; el resurgimiento de las sanciones punitivas y la justicia expresiva, cambios en el tono emocional de la política criminal; el

${ }^{85}$ ZEDNER, "Dangers of Dystopia", cit. nota ${ }^{\circ}$ 2, p. 344.

${ }^{86}$ GARLAND, La cultura, cit. nota ${ }^{\circ} 31$, p. 90.

${ }^{87}$ GARLAND, La cultura, cit. nota ${ }^{\circ} 31$, p. 91.

${ }^{88}$ GARLAND, La cultura, cit. nota ${ }^{\circ}$ 31, p. 92.

${ }^{89}$ GARLAND, La cultura, cit. nota ${ }^{\circ}$ 31, p. 94.

${ }^{90}$ GARLAND, La cultura, cit. nota $\mathrm{n}^{\circ} 31$, p. 110.

91 MARTINSON, Robert, "What Works? -Questions and Answers About Prison Reform", The Public Interest 35:22-54, 1974. Cit.: GARLAND, La cultura, cit. nota $\mathrm{n}^{0} 31$.

${ }^{92}$ GARLAND, La cultura, cit. nota ${ }^{\circ} 31$, pp. 110-117. 


\section{MORALES, Ana María. "La política criminal contemporánea:} Influencia en Chile del discurso de la ley y el orden".

retorno del discurso de la víctima; el privilegio de la protección pública; la politización y el nuevo populismo; la reinvención de las prisiones ("la prisión funciona"); transformación del pensamiento criminológico (volcándose a las que él denomina "criminologías de la vida cotidiana"); la expansión de la infraestructura destinada a la prevención del delito y la seguridad comunitaria; el alistamiento de la sociedad civil en estas materias y el aumento de la seguridad privada; nuevos estilos de gestión y prácticas de trabajo; y finalmente, una "una sensación permanente de crisis". 93

2.1.2. Los riesgos y la inseguridad, y algunas características de la política criminal contemporánea.

Algunos temas recurrentemente analizados en el contexto de la política criminal contemporánea dicen relación con las ansiedades que experimenta cotidianamente la gente en relación al delito y al desorden, y la medida en que éstas se vinculan al surgimiento de una serie de políticas y prácticas en materia de seguridad.

Generalmente, estos postulados se apoyan en teorías sociales vinculadas a la generación de una "sociedad de riesgos", como las expuestas por Beck ${ }^{94}$ o Giddens, ${ }^{95}$ y que sugieren que a partir de los severos cambios que ha sufrido el capitalismo a partir de la década de 1970, las relaciones entre el trabajo y el capital, y entre el sujeto y el Estado, se han trasformado de manera radical. Estos cambios se explican a partir de ciertos rasgos propios de la modernidad tardía, caracterizada por el surgimiento de riesgos globales, un conocimiento indeterminado y contingente acerca de la probabilidad de existencia de esos riesgos, y una incertidumbre acerca de lo venidero y su impacto. ${ }^{96}$ Es así, como algunos autores han caracterizado a este período, como "el fin de la certidumbre", un período caracterizado por la flexibilidad del trabajo, el suministro de capital, la producción global en masa y mercados siempre cambiantes. ${ }^{97}$ En ese contexto, los sujetos del período actual arrastran una serie de inquietudes y preocupaciones, que se vinculan a una búsqueda permanente e incumplida de seguridad. Ésta, a su vez, ha generado el desarrollo por expertos, de una serie de técnicas de cálculo, predicción y manejo de los riesgos, en la pesquisa de la ansiada seguridad.

En la arena particular del sistema penal, el "riesgo" se refiere fundamentalmente a la "probabilidad de cometer un nuevo delito para aquéllos que han sido condenados anteriormente", y que busca generar prácticas basadas en la evidencia, tendientes a asignar las probabilidades a los distintos casos. ${ }^{98}$ En la línea de estos autores, Garland argumenta que la modernidad tardía ha traído aparejada una serie de riesgos e inseguridades, y

\footnotetext{
${ }^{93}$ GARLAND, La cultura, cit. nota no 31, pp. 41-61.

${ }^{94}$ BECK, Ulrick, La sociedad de riesgo global, Madrid: S.XXI Editores, 2002.

95 GIDDENS, Anthony, "The risk society: The context of British Politics", FRANKLIN, Jane (Ed.) The Politics of Risk Society, Cambridge: Polity Press, 1998.

${ }^{96}$ KEMSHALL, Hazel, "Understanding risk in criminal justice", MAGUIRE, Mike (Ed.) Crime and Justice, Berkshire: Open University Press, 2003.

${ }^{97}$ LEONARD, Peter, Postmodern Welfare, Londres: Sage, 1997, Cit.: KEMSHALL, "Understanding risk", cit. nota $\mathrm{n}^{\circ} 96$.

98 SPARKS, Richard, "Degrees of Estrangement: The cultural theory of risk and comparative penology", Theoretical Criminology, 2001 (5): 159-176, p.160. La traducción es de la autora.
} 
problemas de control que han jugado un papel crucial a la hora de dar forma a las respuestas frente al delito. ${ }^{99}$ Ahora bien, aun cuando el autor no desglosa el concepto de riesgos a la manera de Silva, un punto esencial en su análisis radica en que este nuevo enfoque en materia político-criminal, ha cambiado el eje desde la preocupación por la recuperación del infractor, a una filosofía tendiente a proteger al público por sobre todo, y a reducir el riesgo de victimización en el futuro -y hacerlo con un costo mínimo-, lo que se enmarca dentro del trabajo actualmente desarrollado por criminología oficial de corte actuarialista. En ese contexto, resulta indudable la confluencia de la construcción de Garland y de Silva, en términos del rol que asignan al nuevo paradigma asociado al control de riesgos. Sin perjuicio de lo señalado, resulta necesario tener presente, que Silva atribuye un rol creador particular a los riesgos asociados a los medios informáticos e internet, cuya utilización ha traído como consecuencia un desplazamiento hacia la marginalidad a no pocos individuos que son inmediatamente percibidos por los demás como fuentes de riesgos personales que se tornan necesarios de controlar. ${ }^{100}$

En este punto, resulta necesario mencionar los argumentos elaborados bajo el alero de la New Penology (Nueva Penología) por Feeley y Simon, ${ }^{101}$ quienes postulan que la justicia penal ya no está diseñada, como en el paradigma clásico, para castigar proporcionalmente a un sujeto por el daño que causó o como en el paradigma positivista, en torno a la búsqueda de fines tendientes a la rehabilitación o inocuización. Por el contrario, la justicia penal está diseñada para manejar el riesgo de peligro. De esta forma, las sentencias tienen por objeto manejar el riesgo futuro, en el que la teoría de la incapacitación selectiva juega un rol clave. Así, en el ámbito político criminal se estaría utilizando estrategias bajo esa denominación, tendientes a mejorar la posibilidad del sistema de identificar y confinar a aquellos infractores que representan un mayor riesgo para la comunidad, bajo la utilización de herramientas actuariales objetivas. ${ }^{102}$ Esas herramientas a su vez se basan en el manejo de técnicas estadísticas y el cálculo de probabilidades, tendientes a elaborar factores de riesgo a partir de dicha información, usada posteriormente para predecir y generar perfiles de infractores. ${ }^{103}$

Por otro lado, en relación a la inseguridad -temática íntimamente vinculada al debate anterior- y el miedo al delito, es necesario tener presente que en la literatura criminológica se observan a lo menos cinco grandes tesis que buscan indagar sobre los elementos causales vinculados a la inseguridad que se conectan a su vez con el miedo al delito. Uno de estos postulados apunta a establecer conexiones directas con las experiencias de victimización, en las que el miedo al delito es concebido como un producto de ésta. Dicho modelo es sin duda el más simple, pues los niveles de miedo a la delincuencia en una comunidad serían el

\footnotetext{
${ }^{99}$ GARLAND, La cultura, cit. nota no 31, p. 11.

${ }^{100}$ SILVA, Jesús María, "La expansión del Derecho Penal. Aspectos de la política criminal en las sociedades postindustriales", Colección de Estudios y debates en Derecho Penal, Nº1. Buenos Aires: B de F, 2009, p. 30.

101 FEELEY, Malcom, y SIMON, Jonathan, "The New Penology: notes on the emerging strategy of corrections and its implications", Criminology, Volume 30, Issue 4, pp. 449-474, 1992.

${ }^{102}$ GREENWOOD, Peter, Selective Incapacitation, Santa Monica: Rand Publications, 1982.

${ }^{103}$ KEMSHALL, "Understanding risk", cit. nota $n^{\circ} 96$.

${ }^{104}$ Sobre el particular, véase FARRAL, Stephen; GRAY, Emily y JACKSON, Jonathan, "Theorizing the Fear of Crime: The Cultural and Social Significance of Insecurities about Crime", Experience and Expression in the Fear of Crime, Working Paper No. 5, ESRC Grant RES 00023 1108, 2007.
} 
MORALES, Ana María. "La política criminal contemporánea: Influencia en Chile del discurso de la ley y el orden".

reflejo de la actividad criminal dentro de la misma. Así, mientras más directas sean las experiencias o más probable se presente la posibilidad de que un individuo sea víctima de un delito, más miedo tendrá éste. Una segunda explicación apunta a que las personas se preocupan y se sienten inseguras, cuando pueden imaginarse a sí mismas como víctimas. De esta forma, al enterarse de acontecimientos delictuales o conocer a personas que los han sufrido, se sienten más inseguras. Otras explicaciones apuntan a cambios más estructurales que, a su vez, generarían transformaciones a nivel macro-social y a nivel de las comunidades y barrios que al desmembrarse, dan pie a una mayor victimización, a información de segunda mano sobre la realidad delictual, y a mayores niveles de desorden que influirían en el miedo. En otra línea, otros argumentan que lo que se ha medido y conceptualizado como "miedo al delito", tiene sus raíces en algo más difuso que la amenaza de un peligro específico en el entorno inmediato. Así, si bien el público parece estar preocupado por la delincuencia, esta inquietud parece ser más abstracta que concreta, toda vez que las ansiedades acerca del delito se conectan con otras ansiedades. Finalmente, en consonancia con Garland encontramos la idea de que los signos de descomposición de los barrios o comunidades, y el deterioro de los controles sociales, influyen en la percepción pública del riesgo de la delincuencia.

En particular, de acuerdo a la tesis del citado autor, el desmembramiento de las comunidades supone la generación de miedos que van más allá del miedo al delito, y que si bien se encuentran estrechamente relacionados con éste, se concretan en el temor hacia el extraño (en el que delincuente resulta el chivo expiatorio perfecto). En el caso de Silva, su núcleo argumentativo se basa en la institucionalización del fenómeno de la inseguridad, fundamentalmente en la aparición de nuevos riesgos de tipo "objetivo", los que sin embargo se ven acompañados de una sensación social de inseguridad que no necesariamente se condice con el riesgo real. En esa línea, el autor español describe el contexto de aceleración e incertidumbre, de oscuridad y confusión, en que se mueven los individuos en las sociedades contemporáneas, en la $0_{05}$ cuales se producen crecientes desorientaciones personales, y -parafraseando a Smart- un "vértigo de la relatividad" o del "relativismo", como Silva prefiere denominarle. En ese sentido, sus postulados se acercan más a la tesis de entienden que el miedo al delito se encuentra conectado a otras ansiedades propias de la modernidad tardía, donde no hay dudas de su cercanía con términos recurrentes, utilizados en el contexto del análisis crítico relativo a la "inseguridad ontológica", que al igual que el concepto acuñado por Smart, buscan retratar la sensación de precariedad actual. Considerando lo anterior, lo cierto es que tanto las interpretaciones del autor anglosajón como las otorgadas por el autor español, tienen su raigambre en la crisis delomodelo del Estado de bienestar, que ha generado problemas de "vertebración interna".

Otros puntos de conexión entre las citadas obras dice relación con el rol de las víctimas en el discurso político criminal, el que como señala Silva, estaría en consonancia con la auto comprensión de la sociedad de la inseguridad. En este contexto, el citado autor busca ilustrar cómo se ha gestado un fenómeno generalizado de identificación social con la

\footnotetext{
${ }^{105}$ SMART, Barry, Postmodernity, London/ New York: Routledge, 1993. Cit.: SILVA, "La expansión del Derecho Penal", cit. nota n 100.

${ }^{106}$ SILVA, “La expansión del Derecho Penal”, cit. nota no 100, p. 30.
} 
Polit. crim. Vol. 7, № 13 (Julio 2012), Art. 3, pp. 94 - 146.

[http://www.politicacriminal.cl/Vol_07/n_13/Vol7N13A3.pdf]

víctima del delito antes que con el infractor, a diferencia de lo que ocurría en los tiempos correccionales propios de los modelos bienestaristas ${ }^{107}$, como también lo describe Garland en su obra. En la misma línea, otros autores como Hirsch, argumentan que la euforia fijada en la resocialización del infractor de los años 60, ha sido remplazada, por la euforia que recae sobre la víctima. Y es así como, hace ya bastantes años, se ha observado un renovado auge de la victimología, la que si bien partió como una disciplina científica, rápidamente se convirtió en un movimiento internacional de reforma, mostrando sus frutos en las respectivas políticas criminales. ${ }^{108}$ Sobre esta base, es que algunos autores han llegado a entender la pena como un mecanismo de ayuda a la superación por parte de la víctima del trauma generado por el delito, ${ }^{109}$ o han promovido la generación de esquemas paralelos al penal basados en la reparación y la mediación, buscando reconciliar a las víctimas con los infractores, promoviendo, en todos los casos en que sea posible, soluciones "reparadoras", ${ }^{110}$ como la propugnada Braithwaite. ${ }^{111}$

En ese sentido, como expresa Hirsch, sin duda se debe saludar que el ofendido, expulsado del campo de la visión de la política criminal de los años sesenta, sea considerado nuevamente. Sin embargo, esto no debe llevar a plantear las cosas desde una perspectiva unilateral, buscando ampliar las facultades del ofendido a costa de los derechos y garantías del autor, o de reducir el derecho penal a un conflicto entre el ofensor y la víctima, ni de remplazar la pena estatal por prestaciones expiatorias, o en definitiva en tornar borrosa las fronteras entre el derecho penal y el derecho civil sancionatorio. ${ }^{112}$ Así, como sostiene Garland, resulta problemático cuando la inclusión de sus intereses se plantea en términos de un juego político de "suma cero", ${ }^{113}$ donde lo que gana la víctima lo pierde el infractor, y no en términos de un equilibrio entre las pretensiones de aquellos sujetos victimizados con las garantías del debido proceso.

Por otro lado el "gerencialismo" o "managerialismo", también es recogido en la obra de ambos autores, poniendo uno mayor acento en los dispositivos legales del sistema, y el otro, destacando la adaptación de las instituciones penales tradicionalmente resistentes a los estilos de managment. En efecto, Silva analiza este fenómeno considerando los modelos de justicia negociada -en los que también encontramos los mecanismos de mediación y reparación antes expuestos-, donde el derecho penal aparece como un mecanismo de gestión eficiente de determinados problemas, pues permite una mayor focalización. Con esto, señala Silva, se le priva al conflicto delictual de su "sacralización, tradicionalmente

\footnotetext{
${ }^{107}$ SILVA, "La expansión del Derecho Penal”, cit. nota no 100, p. 30.

${ }^{108}$ HIRSCH, Hans Joachim, "Acerca de la posición de la víctima en el Derecho Penal y en el Derecho procesal penal", BOVINO, Alberto y PASTOR Daniel (Eds.), De los delitos y de las víctimas, Buenos Aires: Ad-Hoc, 1992, pp. 93-94.

109 JEROUSCHECK, Gunther, Straftat und Traumatisierung: Uiberlegungen zu Unrecht, Schuld und Rehabilitierung der Strafe aus viktimologischer Perspektive, JZ, 2000. Cit.: SILVA, "La expansión del Derecho Penal", cit. nota ${ }^{\circ} 100$.

${ }^{110}$ GARLAND, La cultura, cit. nota $\mathrm{n}^{\circ} 31$, p. 278.

111 Sobre el particular véase BRAITHWAITE, John, Crime, Shame and Reintegration, Cambridge: Cambridge University Press, 1989.

${ }^{112}$ HIRSCH, “Acerca de la posición de la víctima", cit. nota n 108, pp. 127-128.

${ }^{113}$ GARLAND, La cultura, cit. nota $n^{\circ} 31$ p. 46.
} 
MORALES, Ana María. "La política criminal contemporánea: Influencia en Chile del discurso de la ley y el orden".

propia de lo público, de su contenido simbólico", 114 devolviéndose, en palabras de Christie "el conflicto a las partes". ${ }^{115}$ Garland por su parte argumenta, que este nuevo estilo de managment, que pone el acento en la gestión eficiente de riesgos y recursos, ha producido un sistema "crecientemente selectivo en sus respuestas al delito". Así, se muestra una práctica tendiente a focalizar los recursos, por ejemplo, en aquellas zonas urbanas con altas tasas de delitos, en los infractores reincidentes, en las personas revictimizadas y en los ofensores de alto riesgo. ${ }^{116}$

En relación a lo anterior, Bottoms sostiene que una característica central del enfoque managerialista lo constituye el énfasis en concebir a la justicia penal como un "sistema", más que como una colección de partes diferentes. ${ }^{117}$ Para el citado autor, este acento recurrente en el carácter sistémico, supone abrazar ya sea algunos o todos estos elementos: un énfasis en la cooperación inter-agencia o interinstitucional, en orden a lograr las metas del sistema; la creación de un "plan estratégico" para el conjunto del sistema político criminal en un país determinado, teniendo cada agencia su propia "misión" relacionada de manera integral con las metas generales del sistema. A esto se suma la generación de "indicadores de desempeño" claves relacionados con la misión de cada institución, tendientes a medir aspectos vinculados a la eficacia y efectividad (v. gr. indicadores relativos a "tasas de esclarecimiento", "tasas de sobrepoblación" o "tiempo trascurrido antes del juicio"); y finalmente un monitoreo activo de la información sobre el funcionamiento del sistema, a través de moderna tecnología, en especial concerniente a los indicadores de desempeño. ${ }^{118}$

La politización del discurso político criminal resulta un punto relevante para entender las prácticas actuales de control del delito. El fenómeno de la politización del discurso político criminal, ha sido analizado por algunos bajo el surgimiento en esta arena de discursos que buscan imponer la noción de la "ley y el orden", "19 mientras que otros lo conceptualizan como "populismo punitivo". 120

La expresión relativa a la "ley y orden" es en sí una vieja frase, que tradicionalmente se invoca como si representara un concepto unívoco. En la arena política, esta expresión está íntimamente ligada a la historia de los Estados Unidos y del Reino Unido desde la década de los 60. "La ley y el orden" en primer lugar fue politizada en Norteamérica por Barry Goldwater, aspirante a la presidencia en 1964 de la mano del partido Republicano. A pesar de que Goldwater no resultó elegido, el lema de "la ley y el orden", fue utilizado con éxito en la campaña presidencial de Richard Nixon en $1968 .^{121}$

\footnotetext{
${ }^{114}$ SILVA, "La expansión del Derecho Penal”, cit. nota n 100, p. 82.

${ }^{115}$ CHRISTIE, Nils, “Conflicts as property”, British Journal of Criminology, 17 (1): 1-15, 1977.

${ }^{116}$ GARLAND, La cultura, cit. nota $\mathrm{n}^{\mathrm{0}}$ 31, p. 58.

117 BOTTOMS, Anthony, "The Philosophy and Politics of Punishment and Sentencing", en CLARKSON, Chris y MORGAN, Rod (Eds.) The Politics of Sentencing Reform, Oxford: Clarendon Press, 1995, p. 24-25. La traducción es de la autora.

${ }^{118}$ BOTTOMS, "The Philosophy and Politics", cit. nota no 117, p. 18.

${ }^{119}$ HALL, Stuart, Drifting to a Law and Order Society. Londres: Cobden Trust, 1980. La traducción es de la autora.

${ }^{120}$ BOTTOMS, “The Philosophy and Politics", cit. nota $\mathrm{n}^{\mathrm{o}} 117, \mathrm{p} .18$.

${ }^{121}$ REINER, Robert, Law and Order, Cambridge: Polity Press, 2007.
} 
Polit. crim. Vol. 7, № 13 (Julio 2012), Art. 3, pp. 94 - 146.

[http://www.politicacriminal.cl/Vol_07/n_13/Vol7N13A3.pdf]

De acuerdo a Reiner, la demanda de ley y el orden condensa un significado específico: por encima de todo, lo que la ley puede y debe producir es orden, y en los casos en que esto no ocurre, se debe a una débil aplicación de ésta. Bajo dicha mirada, el propósito inequívoco es el control del delito a través de la ley, lo que muchas veces se ve frustrado debido a las restricciones propias del debido proceso que atentan contra una aplicación efectiva. Uno de los autores más influyentes para este enfoque es Wilson, quien con su libro "Thinking about crime" (Pensando en el delito), editado en 1975, entregó una visión realista de la delincuencia y el control. En esa obra, el citado autor sostiene que la clave de la lucha contra la delincuencia radica en incrementar los costos a los delincuentes potenciales, aumentando la probabilidad y la intensidad de las penas. Esta postura fue congruente con el resurgimiento de las perspectivas clásicas y económicas, que explican la delincuencia como el producto de elecciones racionales de los individuos libres. ${ }^{122}$

Considerando lo anterior, Cavadino y Dignan sostienen que la ideología de la ley y el orden no es simplemente la creencia de que la sociedad debe ser gobernada por la ley, sin excepciones, y el delito efectivamente controlado, sino que es "un conjunto complejo e ingenuo de actitudes, que incluye la creencia de que los seres humanos tienen libre determinación, que pueden ser estrictamente disciplinados por reglas restrictivas, y que deben ser severamente castigados si quiebran las reglas o fallan en respetar la autoridad". 23

Otros identifican estas manifestaciones bajo el término de "populismo punitivo", concepto acuñado por Anthony Bottoms, y que se utiliza para describir uno de los factores más relevantes presentes en el diseño de las políticas públicas en la arena de la justicia criminal, y que apunta a recoger la idea de que los "políticos aprovechan y utilizan para sus propios fines lo que ellos creen que es una postura punitiva del público en general". ${ }^{124}$ En ese contexto, se hace referencia al Derecho Penal, defendiendo tesis político criminales asociadas a la necesidad del aumentar las penas como una forma de reducir las tasas delictuales, o el postulado de que las penas refuerzan determinados consensos morales, esenciales para la vida en sociedad. ${ }^{125}$

La politización del discurso político criminal es analizada de manera bastante aguda por Garland, quien argumenta que el proceso de generación de las políticas públicas en esta materia se ha vuelto profundamente "politizado y populista". ${ }^{126}$ Así, en palabras del citado autor, "esta tarea ya ha dejado de ser un asunto bipartidista que puede delegarse en expertos profesionales y se ha convertido en un asunto medular en la competencia electoral". ${ }^{27}$ En la misma línea, sostiene que el proceso de generación de las políticas públicas en esta materia no necesariamente se ha traducido en una polarización como ocurría en épocas pasadas. Así, como señala, "lejos de haber una diferenciación de posturas en materia política criminal, lo que realmente ha sucedido en las décadas de 1980 y 1990 es el

\footnotetext{
${ }^{122}$ REINER, Law and Order, cit. nota $\mathrm{n}^{\circ} 121$.

123 CAVADINO, Michael y DIGNAN, James, The Penal System, Londres: Sage, 1997, p. 25. La traducción es de la autora.

${ }^{124}$ BOTTOMS, “The Philosophy and Politics”, cit. nota no 117, p. 40.

${ }^{125}$ BOTTOMS, “The Philosophy and Politics", cit. nota $\mathrm{n}^{\circ} 117, \mathrm{p} .39$.

${ }^{126}$ GARLAND, La cultura, cit. nota $\mathrm{n}^{\circ} 31$, p. 49.

${ }^{127}$ GARLAND, La cultura, cit. nota $n^{\text {o }} 31$, pp. 48-49.
} 
MORALES, Ana María. "La política criminal contemporánea: Influencia en Chile del discurso de la ley y el orden".

empobrecimiento del debate y una llamativa convergencia de propuestas políticas entre los principales partidos políticos". 128

Por otro lado, Silva también encuentra en la arena europea ejemplos de concordancias entre las ideas político criminales de bloques opuestos. Sin embargo, a diferencia de Garland, y concretando su análisis en el caso particular de la izquierda parlamentaria española, el citado autor deja de lado los usuales argumentos populistas y puramente centrados en los beneficios electoralistas, aludiendo a cierta esquizofrenia o ambivalencia en su relación con el derecho penal que presentaría dicha ala política, la que podría ser rastreada mucho antes de las actuales manifestaciones. De esta forma, describe el autor, ya en los años setenta, bloques políticos como los señalados, si bien sostenían discursos cuya leit-motiv era la "lucha de clases", también revelaban un doble baremo a la hora de valorar la intervención del derecho penal. Así, por un lado se negaba legitimidad al derecho penal partiendo de las corresponsabilidad en la génesis del delito y su inutilidad en el contexto de sociedades escindidas, mientras por el otro, se propugnaba al derecho penal como un mecanismo de trasformación social y de intervención frente a aquéllos que impidieren avanzar hacía sociedades más igualitarias. ${ }^{129}$

Lo expuesto anteriormente sin duda resulta relevante, pues pone en evidencia las profundas diferencias de los planteamientos actuales con los discursos de la ley de orden primigenios, que más bien buscaban realzar las diferencias existentes entre los bloques opuestos, en el modo de enfrentar el delito. De esta forma, como precisa Silva, el antiguo debate en torno a la ideología de la ley y el orden, suponía que los partidos tradicionalmente calificados como de "derecha" asumieran la tesis del incremento punitivo de la seguridad a través de una mayor presión punitiva, mientras que los partidos calificados de "izquierda" abogaran por la postura contraria, tendiente a obtener una menor presión punitiva, ${ }^{130}$ diferencias que en la actualidad prácticamente se han suprimido.

Un punto de inflexión importante entre ambas obras, dice relación con la importancia asignada a la delincuencia clásica y a la delincuencia económica frente a los fenómenos analizados. En ese sentido, para Garland el principal objetivo de las políticas criminales propias de esta nueva cultura sigue siendo el control de la delincuencia clásica protagonizada por sujetos marginales, los clásicos "pobres, peligrosos e indignos", los "underclass" 131 y que constituyen una clase aparte, "un residuo desechado por los procesos de alta tecnología y ritmos acelerado de la economía globalizada y la sociedad de la información". 132

En la vereda opuesta, Silva argumenta que aspectos comentados como los relativos a los riesgos, la inseguridad, el rol de las víctimas y la construcción eminentemente política del discurso penal, han cobrado un impulso importante a partir de dos fenómenos que se muestran como típicos de la sociedades postindustriales: la globalización económica y la

\footnotetext{
${ }^{128}$ GARLAND, La cultura, cit. nota $\mathrm{n}^{\circ} 31$, p. 50.

${ }^{129}$ SILVA, "La expansión del Derecho Penal", cit. nota $\mathrm{n}^{\circ} 100, \mathrm{p} .72$.

${ }^{130}$ SILVA, "La expansión del Derecho Penal”, cit. nota n 100, p. 69.

${ }^{131}$ GARLAND, La cultura, cit. nota $\mathrm{n}^{\circ}$ 31, p. 297.

${ }^{132}$ GARLAND, La cultura, cit. nota $\mathrm{n}^{\mathrm{o}} 31$, p. 317.
} 
Polit. crim. Vol. 7, № 13 (Julio 2012), Art. 3, pp. 94 - 146.

[http://www.politicacriminal.cl/Vol_07/n_13/Vol7N13A3.pdf]

integración supranacional. En esa línea, el académico afirma que la delincuencia de la globalización es esencialmente económica y que en ella la reflexión jurídico-penal tiene "por primera vez, como objeto esencial de estudio delitos claramente diversos del paradigma clásico (el homicidio o la delincuencia patrimonial tradicional)", los que en la criminología son abordados bajo la expresión de "the crimes of the powerful" (delitos de los poderosos). ${ }^{133}$ En este contexto, el paradigma político criminal de la globalización es el delito económico organizado tanto en su modalidad empresarial convencional, como en las modalidades de la llamada macrocriminalidad: terrorismo, narcotráfico o criminalidad organizada (trafico de armas, mujeres o niños). ${ }^{134}$

Considerando lo anterior, si bien ambos autores reconocen cambios profundos en la política criminal y a su vez presentan varios puntos de convergencia en términos de las estructuras causales de dichos cambios, no existe duda que el modelo político criminal resultante de dichas trasformaciones que tienen en mente es sustancialmente distinto. En ese sentido, resulta justo aclarar que Silva reconoce que aún es posible afirmar que el $80 \%$ de la criminalidad continúa manifestándose como criminalidad de los marginados. Sin embargo, para él resulta evidente que la esencia de la política criminal fruto de esos cambios está constituida por la criminalidad de los poderosos y de las empresas. ${ }^{135}$

Ése es, sin duda, uno de los puntos sensibles de la obra de Silva, pues denota un cierto distanciamiento de las realidades político criminales de los países que precisamente han sido fruto de su examen. En esa línea, los argumentos de otro catedrático español, José Luis Diez, resultan atingentes en la medida que contienen una fuerte crítica que va precisamente en la línea de lo señalado. Así, el citado autor argumenta que Silva a partir de la segunda edición de su obra "La expansión del derecho penal", ha caído en cuenta que el fenómeno de la expansión de la criminalización no gira en torno de las nuevas formas de delincuencia "socioeconómica" -como las denomina-, sino que en derredor de la delincuencia clásica a partir de las demandas "ley y orden". ${ }^{136}$ En efecto, Diez precisa que Silva habría confundido la llamada "modernización" del derecho penal, orientada fundamentalmente a la criminalidad de los "poderosos" con las demandas de "seguridad ciudadana", que son dirigidas en mayor forma contra la "delincuencia callejera y clásica y, por tanto, contra los sectores sociales más desfavorecidos y los marginados". ${ }^{137}$

Por otro lado, yendo más allá en su examen, Diez sostiene que muchos de los argumentos de cambio se basan en concepciones tergiversadas de las "sociedad de riesgo", en la medida que equiparan los riesgos derivados del uso de las nuevas tecnologías con aquéllos que se encuentran asentados en la vida cotidiana. Esto sin duda no resulta frívolo, si entendemos que el discurso político criminal que se deja guiar por demandas mediáticas y coyunturales, no suele fijar predominantemente su atención en la criminalidad de los nuevos riesgos. ${ }^{138}$

\footnotetext{
${ }^{133}$ SILVA, "La expansión del Derecho Penal”, cit. nota no 100, p. 85-86

${ }^{134}$ SILVA, "La expansión del Derecho Penal”, cit. nota n 100, p. 106.

${ }^{135}$ SILVA, "La expansión del Derecho Penal”, cit. nota no 100, p. 53.

136 DIEZ, José Luis, La política criminal en la encrucijada, Colección de Estudios y debates en Derecho Penal, No3. Montevideo/Buenos Aires: B de F, 2007, p. 154.

${ }^{137}$ DIEZ, La politica criminal, cit. nota $\mathrm{n}^{\circ} 136$, p. 154.

${ }^{138}$ DIEZ, La politica criminal, cit. nota ${ }^{\circ} 136$, p. 154.
} 
En el contexto de lo señalado, el citado autor recoge en su obra la mayoría de los indicadores de cambio político-criminales que recoge Garland en la "La Cultura del control"139 a partir de los cuales postula la generación de un nuevo modelo político criminal de la "Seguridad Ciudadana". En la construcción de esos indicadores, en consonancia con lo señalado, juega un lugar fundamental el protagonismo que sigue teniendo la delincuencia clásica en la generación de este nuevo modelo. En esa línea, Diez plantea que el nuevo modelo de la seguridad ciudadana tendría en su base más que una expansión del derecho penal, una intensificación de éste, de manera que las decisiones político criminales concentran sus esfuerzos en incrementar la punición de ciertos tipos penales, propios de la delincuencia clásica.

Por otro lado, argumenta el autor que la adopción de este modelo, supone aceptar que nuestras sociedades presentan indiscutibles altas tasas de miedo al delito y que la opinión pública en general es inaccesible a los esfuerzos de sensibilización, por lo que resulta necesario desplegar medidas orientadas a calmar sus temores. En ese sentido, encontramos el presupuesto en virtud del cual se afirma la incapacidad de las estructuras penales convencionales para abarcar la delincuencia tradicional de los marginados, en los que argumentos relativos a hacerse cargo "de las causas" de la delincuencia, usualmente dan lugar a cuestionamientos sobre los elevados costos de la intervención. Del mismo modo, se da por sentado que en los casos de delincuencia grave no queda otro camino que el de la inocuización. ${ }^{140}$

De esta forma, la citada "expansión" a juicio de Diez, ya no apunta, como se pensó en sus orígenes, a la delincuencia organizada propia de las grandes y complejas organizaciones criminales, sino a las manifestaciones asociativas ligadas a la delincuencia tradicional, como las bandas de asaltantes o secuestradores, los traficantes ilícitos pertenecientes a las estructuras intermedias, las redes de pornografía infantil, y los grupos ideológicos o pandilleros violentos, a lo cual se añade la persecución de las bandas terroristas. ${ }^{141}$

\subsection{Las razones tras la severidad chilena.}

En el ámbito nacional, es posible rastrear tanto en la dogmática penal como en el escaso debate criminológico, autores que han recogido tesis como la de Garland o Diez, ${ }^{142}$ y otros que a su vez han hecho eco de la expansión del derecho penal bajo las tesis de Silva. ${ }^{143}$ En buenas cuentas, la mayoría ha reconocido que en nuestra política criminal se ha producido un giro importante, orientado a una mayor intervención punitiva.

\footnotetext{
${ }^{139}$ Véase supra p. 22.

${ }^{140}$ DIEZ, La política criminal, cit. nota $\mathrm{n}^{\circ} 136$, p. 154.

${ }^{141}$ DIEZ, La politica criminal, cit. nota $\mathrm{n}^{\circ} 136$, p. 158-163.

${ }^{142}$ Así por ejemplo FERNÁNDEZ, "El nuevo código penal”, cit. nota $n^{\circ} 56$.

143 Sólo a modo ejemplar CARNEVALI, Raúl, "Derecho Penal como Ultima Ratio. Hacia una política criminal racional", Ius et Praxis, 14, N¹, 13, 2008; FELLER, Claudio, "El derecho penal en la sociedad actual: un riesgo para las garantías penales", Revista de Derecho de la Pontificia Universidad Católica de Valparaíso, XXVI, Semestre I, 2005, pp. 41-52. Éste último autor, si bien parte de la base a la existencia de una expansión a la manera Silva, no concuerda en la tesis político criminal propuestas por dicho autor para hacerse cargo de la citada expansión, como es aquella relativa al Derecho penal de dos y hasta tres velocidades.
} 
Polit. crim. Vol. 7, № 13 (Julio 2012), Art. 3, pp. 94 - 146.

[http://www.politicacriminal.cl/Vol_07/n_13/Vol7N13A3.pdf]

Considerando dicho contexto, a continuación se analizará la pertinencia de los argumentos entregados por los autores examinados anteriormente para entender la situación nacional, y adicionalmente se entregará algunas perspectivas particulares que resultan importantes tener en consideración.

El primer punto dice relación con la pertinencia del debate relativo a las "sociedades de riesgo" en el escenario nacional y como estás han permeado nuestra legislación. Resulta indudable poder constatar que al igual que lo descrito especialmente por Garland y Silva, la sociedad chilena se encuentra expuesta a mayores riesgos, ante lo cual ha surgido la necesidad de otorgar protección penal a esos nuevos intereses, hasta ahora inexistentes o no considerados en la misma medida. Algunos ejemplos de nuevos intereses, y sin pretender un exhaustivo análisis, los encontramos en algunas regulaciones contenidas en materia económica, ${ }^{144}$ como es el caso de la Ley $\mathrm{N}^{\circ} 19.913$ que reguló el lavado de dinero, y la N²0.009 que sancionó el uso fraudulento de tarjetas de crédito. En el mismo sentido, en materia de delincuencia informática, la Ley $\mathrm{N}^{\circ} 19.233$ reguló por primera vez, y de manera bastante tímida, los delitos de este orden.

Por otro lado, también encontramos ejemplos de riesgos que aunque existentes, se encontraban de cierta forma invisibilizados, o donde se han ido generando nuevas formas de lesión de bienes jurídicos no reconocidos por la legislación. Ejemplo de ello lo encontramos en la Ley $\mathrm{N}^{\circ} 20.066$ sobre violencia intrafamiliar, y en algunas de las reformas a los delitos sexuales, como las analizadas en el capítulo anterior. Asimismo, la Ley $\mathrm{N}^{\circ} 20.253$ de "agenda corta antidelincuencia", también contempla criterios asociados a un mayor control de grupos de riesgos existentes, en particular en aquellas ofensas calificadas por la ley como "serias", y que dicen relación, principalmente, con delitos sexuales, homicidios, robos y algunos contenidos en la ley de drogas. Así, en la lógica de Silva, encontraríamos cierta selectividad en el sentido de otorgar una respuesta más enérgica en aquellas conductas que generan más riesgos desde la perspectiva del daño que, a juicio del legislador, podrían producir a la sociedad.

Por otro lado, desde la perspectiva criminológica, aun considerando que ésta es una arena de escaso desarrollo en nuestro país, y donde las intervenciones -salvo excepciones- no se basan en la evidencia internacional, se observan tímidamente algunas prácticas en la línea del control de riesgos donde se evidencia una suerte de selectividad en la respuesta del sistema penal. Ejemplos de lo anterior se encuentran en la evaluación de riesgo para la víctima, desarrollada en el contexto de la investigación de delitos de violencia intrafamiliar, y en virtud de los cuales el Ministerio Público se apoya para efectos de brindar protección a las víctimas, fundamentalmente mediante la solicitud de imposición de medidas cautelares. $^{145}$

Íntimamente vinculado con lo anterior encontramos el fenómeno de la inseguridad, y como ya pudimos observar, en Chile el temor es elevado, lo que se desprende de las cifras

\footnotetext{
${ }^{144}$ Para mayor detalle véase HERNÁNDEZ, Héctor "Perspectivas Del Derecho Penal Económico En Chile", Persona y Sociedad, XIX, №1, 2005, pp. $101-134$.

${ }^{145}$ Sobre el particular véase RIOS, Erick, Experiencias de evaluación de riesgo y seguimiento en Chile, Santiago: Centro de Estudios de Justicia de las Américas, 2010.
} 
MORALES, Ana María. "La política criminal contemporánea: Influencia en Chile del discurso de la ley y el orden".

recogidas por las encuestas de victimización. En particular, si comparamos las cifras nacionales, con los índices de temor de países desarrollados, encontramos que nuestro país está muy por sobre la media (28\%), con un 48,3\% de los encuestados que declara sentirse inseguro en la calle, durante la noche. ${ }^{146}$ Por otro lado, en el contexto Latinoamericano, la mayoría de los países evidencia alto temor. Esto se ve reflejado en que, en promedio, el $58 \%$ de los encuestados afirma que vivir en sus respectivos países es cada vez más inseguro, cifra que el caso chileno desciende un $43 \% .{ }^{147}$ Sobre el particular, al menos dos análisis efectuados en Chile, uno hecho por el Programa de las Naciones Unidas para el Desarrollo (PNUD) en Chile, ${ }^{148}$ y otro por Dammert y Malone, ${ }^{149}$ han buscado demostrar que el temor al delito es el producto de un amplio conjunto de inseguridades económicas, sociales y políticas. Ambos estudios se ajustan en términos de sus conclusiones a la línea argumentativa de Garland, en la medida que entienden que la inseguridad descansa, más allá de las tasas reales de delito, sobre la imagen metafórica de un delincuente omnipotente $\mathrm{y}$ omnipresente, que condensa un temor generalizado y, por lo mismo, exagerado, otorgándose así un nombre a una realidad difícil de asir. En ese sentido, las segundas autoras argumentan que tras el creciente temor al crimen se encarna la imagen de "el extraño temible, el excluido", lo que a su vez empaña la naturaleza real del crimen y disminuye la importancia de otras inseguridades en la vida de los ciudadanos. ${ }^{150}$

Desde otra perspectiva, resulta bastante sencillo rastrear la importancia de los movimientos de apoyo a las víctimas y su influencia en la política criminal chilena. Un ejemplo bastante concreto lo encontramos a propósito de la generación de denominada "agenda corta antidelincuencia", en cuyo mensaje se observa el discurso central relativo a la necesidad de brindar mayor protección a las víctimas a través de instrumentos como el señalado. La tramitación de esta normativa fue a su vez presionada por una organización creada unos años antes de su publicación, la que reunió firmas y concitó un fuerte apoyo con el objetivo principal de "remecer a las autoridades de gobierno, judiciales y a los parlamentarios, para que realicen los cambios legales que aseguren que "los delincuentes tengan castigos ejemplarizadores"'. ${ }^{151}$ En ese contexto, se promovió un intenso debate entorno a la necesidad de establecer de manera explícita el derecho de defensa de las víctimas, junto con la creación de una Defensoría especializada en su atención. En particular, la primera de estas propuestas, se plasmó en una reforma al número $3^{\circ}$ del artículo 19 de la Constitución, estableciéndose la asesoría y defensa jurídica gratuita de las víctimas de delito para efectos del ejercicio de la ley penal, en virtud de la Ley $\mathrm{N}^{\circ} 20.516$.

Por otro lado, Chile al igual que otros países de la región, presenta una prevalencia de vida importante en violencia intrafamiliar, esto es, de personas que señalan haber sufrido esta

\footnotetext{
${ }^{146}$ Ver en Anexo Gráfico No 7.

${ }^{147}$ Ver en Anexo Gráfico No 8.

${ }^{148}$ PNUD, Desarrollo Humano en Chile 1998. Las Paradojas de la Modernización, Santiago: PNUD, 1998.

149 DAMMERT, Lucía y MALONE, Mary, "Fear of Crime or Fear of Life? Public Insecurities in Chile", Bulletin of Latin American Research, 22 (1):79-101, 2003. La traducción es de la autora.

${ }^{150}$ DAMMERT/MALONE, "Fear of Crime", cit. nota ${ }^{\circ} 149$, p. 80.

${ }^{151}$ Las Ultimas Noticias, 30 de mayo, 2006.
} 
Polit. crim. Vol. 7, № 13 (Julio 2012), Art. 3, pp. 94 - 146.

[http://www.politicacriminal.cl/Vol_07/n_13/Vol7N13A3.pdf]

situación alguna vez durante su vida. ${ }^{152}$ En ese contexto, también se ha observado importantes movimientos de organizaciones apoyadas por representantes del Parlamento que han buscado como respuesta a éste fenómeno un endurecimiento de la respuesta penal, cuestión que a su vez ha sido apoyada acríticamente por los distintos gobiernos, adoptando las perspectivas feministas como modelo teórico oficial, bajo lo que Larrauri denomina "feminismo oficial". ${ }^{153}$ Lo anterior ha llevado a cambios dramáticos en nuestra legislación penal como es el caso de la Ley de violencia intrafamiliar ya mencionada, ${ }^{154}$ y la Ley $\mathrm{N}^{\circ}$ 20.480 que vino a tipificar el delito de femicidio. Esta última norma ha sido criticada por autores como Hernández, en la medida que ha implicado seguir expandiendo la "reliquia injustificable" que es el delito de parricidio, y que en lugar de apuntar al diseño de un régimen de protección penal de las mujeres frente a la violencia de género, "insiste en intervenir tipos penales generales, provocando graves distorsiones, tanto en términos de certeza como en términos de proporcionalidad". ${ }^{155}$ En ese sentido resulta necesario hacer presente que lo anterior no apunta a omitir en el diseño político criminal las legítimas pretensiones que pudiesen tener estos actores, sino más bien a evitar que se plantee el endurecimiento de la respuesta penal como la única vía de satisfacción de los intereses de la víctima. Lo mismo ocurre cuando el foco se centra en la disminución de las garantías del debido proceso, como la fórmula adecuada para enfrentar sus pretensiones, en un enfoque unidimensional. En esa línea, resulta particularmente relevante reconocer la importancia de otorgar medidas de protección, como lo recalca Hernández, especialmente de aquellas víctimas vulnerables, las que deben necesariamente ir de la mano con la generación de estrategias de tipo preventiva que resulten idóneas.

El fenómeno del "gerencialismo" o "managerialismo" también lo encontramos presente en el diseño de nuestra política criminal contemporánea, particularmente en la línea de lo expuesto por Silva en relación al reconocimiento de una selectividad propia del sistema y la introducción de los modelos de justicia negociada. Ejemplos de lo anterior, se observan en la regulación de institutos como la suspensión condicional del procedimiento, los acuerdos reparatorios y la regulación del procedimiento abreviado, incluidos en la reforma procesal penal. En la misma línea, la Ley $\mathrm{N}^{\circ} 20.084$ de responsabilidad penal adolescente, también recoge esquemas de justicia negociada, mediante el reconocimiento de instituciones como las señaladas, y el establecimiento de sanciones como los servicios en beneficios de la comunidad y la reparación del daño, tendientes a buscar soluciones más "restaurativas", coincidiendo a su vez con aquellas perspectivas que buscan reconciliar a las víctimas con los infractores.

Sobre el particular, es necesario tener presente que el modelo asociado al gerencialismo no es per se negativo, pues mediante él se logra divertir del sistema penal aquellas causas que no generan una lesión grave de determinados bienes jurídicos, concretando de alguna

\footnotetext{
${ }^{152}$ De acuerdo a la Encuesta Nacional de Victimización por Violencia Intrafamiliar y Delitos Sexuales, la prevalencia de vida de la violencia intrafamiliar, es del $72.3 \%$ en los niños, del $35,7 \%$ en las mujeres y del 19,8\% en los adultos mayores. Ministerio del Interior y Pontificia Universidad Católica de Chile, 2008.

${ }^{153}$ LARRAURI, Elena, Criminología crítica y violencia de género. Barcelona: Editorial Trotta, 2006.

${ }^{154}$ Sobre sus efectos en la política criminal chilena, véase, JIMÉNEZ, María Angélica y MEDINA, Paula, Violencia contra la pareja. Mayores penas, mayor violencia. Santiago: Librotecnia, 2011.

${ }^{155}$ HERNÁNDEZ, Héctor, "Ley de femicidio (o la incapacidad técnica de la propaganda)" en El Mercurio Legal, 16 de Agosto, 2011.
} 
MORALES, Ana María. "La política criminal contemporánea: Influencia en Chile del discurso de la ley y el orden".

manera el principio de la última ratio. Los problemas en general se producen en la línea de lo expuesto por Garland, cuando estos mecanismos son utilizados para beneficiar a determinados grupos de población por razones distintas del propio acto delictual, o cuando en la práctica opera regresivamente respecto de ciertos sectores de la población, como lo demuestran estudios comparados que han observado una selectividad tendiente a perjudicar a determinados grupos, de acuerdo a criterios como la edad, la marginalización, el origen racial, $u$ otros. ${ }^{156}$

Por otro lado, y en la línea de lo expuesto por Bottoms en esta materia, la presentación de una "Estrategia Nacional de Seguridad Ciudadana", por primera vez en el año 2006, precisamente apunta a concebir al sistema penal con un carácter integral, entendiéndolo como un sistema con énfasis en la generación de estrategias de tipo interinstitucionales, tendientes a reducir la victimización de la población. Esta estrategia se estructura a partir de seis ejes fundamentales: la institucionalidad, la información, la prevención, el control y la sanción, la rehabilitación y reinserción social, y la asistencia a víctimas. Dichos ejes, a su vez, están asociados a distintas instituciones, las que son coordinadas y supervisadas en su ejecución por el Ministerio del Interior. De esta forma, como lo precisa su mensaje, la citada estrategia buscó "consolidar una política pública de alta eficiencia y eficacia, capaz de responder a criterios centrales en la gestión gubernamental. De esta forma, se refuerza una política integral que aborda en profundidad los desafíos en ámbitos tan diversos como la Prevención o el Control del delito, con iniciativas ejecutadas por los organismos especializados para cada eje de acción." 157

La politización del discurso político criminal, como se pudo observar en los capítulos anteriores es bastante tangible en nuestra realidad y, efectivamente, en la campaña previa a la elección presidencial del año 2000, el discurso político asociado al control de la criminalidad tendió a endurecerse. En ese contexto, y en la línea de lo planteado tanto por Garland como por Silva, se observa una suerte de convergencia en términos de las propuestas políticas en esta materia, como pudo desprenderse del análisis de las promesas de campaña. Así, la mayoría de las propuestas de los principales bloques en los períodos analizados, se concentraron en entregar respuestas más enérgicas frente a la criminalidad, tendientes a hacerse cargo de la delincuencia habitual y a proponer medidas más efectivas para controlar a aquellos infractores persistentes o "profesionales", conforme las expresiones utilizadas de manera usual en los escenarios electorales. En ese sentido, en el contexto Latinoamericano, autores como Chevigni, han vinculado la existencia de altas tasas de temor que se observan en la región con una suerte de instrumentalización electoral de esta temática. De esta forma, se ha sugerido el surgimiento de lo que él denomina "el populismo del temor", como un rasgo claro del escenario latinoamericano contemporáneo. En ese sentido este autor sostiene que "ha habido una tendencia política en orden a apelar al miedo al delito como una temática popular en las campañas electorales, y también, generalmente, como una manera de atraer la atención del público (...). Bajo esas condiciones, hay una fuerte tentación de encontrar un tema que atraiga a todas las clases

\footnotetext{
156 Véase por ejemplo, PHILLIPS, Coretta y BOWLING, Ben, "Racism, Ethnicity, Crime and Criminal Justice", en MAGUIRE, Mike, MORGAN, Rod, RAINER, Robert (Eds.) The Oxford Handbook of Criminology, Oxford: Oxford University Press, $3^{\circ} \mathrm{Ed}, 2002$.

${ }^{157}$ Estrategia Nacional de Seguridad Pública (2006-2010), p. 7.
} 
Polit. crim. Vol. 7, № 13 (Julio 2012), Art. 3, pp. 94 - 146.

[http://www.politicacriminal.cl/Vol_07/n_13/Vol7N13A3.pdf]

sociales: el problema del delito y el consiguiente temor de inseguridad es un tema obvio que se usa frecuentemente y es a veces exagerado con la esperanza de atraer el apoyo popular". 158

A esto es necesario sumar un elemento que debe ser considerado con ciertas reservas. Algunos estudios nacionales han buscado comprobar que efectivamente la introducción de medidas más severas en materia de delincuencia cuenta con apoyo popular. Así, por ejemplo, una encuesta realizada recientemente por el MIDE UC a un total 1.476 personas, reflejó que el 96\% está de acuerdo con aplicar "mano dura" a los delincuentes. Asimismo, en este estudio, los propósitos del castigo más mencionados fueron "proteger a la comunidad" y "aumentar la seguridad y el orden". ${ }^{159}$ En ese sentido, los resultados de estas encuestas de cierta forma legitimarían la introducción de medidas punitivas y frente a esto no llama la atención el que "legisladores, políticos, jueces e incluso otros profesionales del sistema de justicia regularmente citan la opinión pública al momento de diseñar o implementar una política pública". ${ }^{160}$ Sin embargo, este tipo de estudios de opinión desconocen los hallazgos de buena parte de la criminología moderna que han buscado entender las actitudes públicas respecto del castigo y que han relevado la importancia de realizar investigaciones que permitan indagar sobre las mismas. Así, por ejemplo, Bottoms plantea que se ha demostrado que si bien se puede encontrar "un considerable apoyo popular de políticas punitivas cuando se consultan en las encuestas preguntas generales y abstractas, la situación es distinta cuando se formulan preguntas sobre situaciones específicas en que los consultados tiene información más detallada (incluidos aquellos casos en que los consultados son efectivamente víctimas)". ${ }^{161}$ En efecto, el mismo autor concluye que, en este último caso, en el que se consulta a sujetos que han sido victimizados, las penas por ellos sugeridas están mucho más cerca de aquellas efectivamente impuestas por los jueces. ${ }^{162}$ Aun más, otros autores sostienen que si los miembros de la población son informados respecto de un determinado hecho delictivo, estos tienden a ser menos punitivos que los jueces al momento hipotético de dictar sentencia. ${ }^{163}$

Un punto relevante y que resulta necesario tener presente para entender el contexto nacional, lo constituye el hecho que de acuerdo a la información estadística disponible, entre el período 1973-2003, las cifras delictuales (denuncias) referidas a los delitos contra la propiedad se triplicaron mientras que aquéllas contra las personas aumentaron en un

\footnotetext{
${ }^{158}$ CHEVIGNY, Paul, "The Populism of Fear: Politics of Crime in the Americas", Punishment and Society, 5 (1): 77-96, 2003, p. 77. La traducción es de la autora.

159 CASTILLO, Juan Carlos; MANZI, Jorge; LEAL, Paola; MADERO, Ignacio, "Percepción de riesgo, confianza en los Tribunales y actitudes hacia la penalización”, Informes técnicos MIDE UC, 2011.

160 ROBERTS, Julian y HOUGH, Michael, "Public attitudes to punishment: the context", en ROBERTS, Julian y HOUGH, Michael (Eds.) Changing Attitudes to Punishment, Public opinion, crime and justice. Londres. Willan Publishing, 2002, p. 1. La traducción es de la autora.

${ }^{161}$ BOTTOMS, "The Philosophy and politics", cit. nota $\mathrm{n}^{\circ} 117$, p. 40.

${ }^{162}$ BOTTOMS, "The Philosophy and Politics", cit. nota $\mathrm{n}^{\circ} 117$.

163 WARNER, Kate; DAVIS, Julia; WALTER, Maggie; BRADFIELD, Rebecca, y VERMEY, Rachel, "Public judgment on sentencing: Final results from Tasmanian Jury Sentencing Study". Trends \& Issues in crime and criminal justice, Australian Institute of Criminology, $\mathrm{N}^{\circ}$ 407, 2011.
} 
MORALES, Ana María. "La política criminal contemporánea: Influencia en Chile del discurso de la ley y el orden".

$100 \%,{ }^{164}$ situación que empeoró entre 1998 y 2003, período en el que las cifras aumentaron exponencialmente. ${ }^{165}$ Luego del lanzamiento de la primera ENUSC en 2003, la información disponible, relativa a victimización en los hogares, comenzó a registrar una tendencia hacia la baja. De esta forma, es posible observar una disminución de 14.8 puntos porcentuales en la victimización general, entre 2003 y $2010 .{ }^{166}$ Con lo anterior se pretende en definitiva argumentar que el surgimiento a nivel político de los discursos con retóricas asociados a la "ley y el orden" o un "populismo punitivo" en Chile, se encuentra estrechamente relacionado con un aumento de la criminalidad entre 1998 y 2003, destacando el incremento de las denuncias de los "delitos de mayor connotación”. Así, en dicho período comenzaron a emerger los discursos políticos asociados a las exigencias de "mano dura" con un fuerte contenido populista en materia de seguridad ciudadana. De esta forma, el surgimiento de estas retóricas surge como una respuesta realista y pragmática a dichas alzas, actuando como una suerte de elemento justificatorio.

Por otro lado, como se observó en el capítulo anterior, parece ser que nuestra sociedad y en particular nuestros legisladores han internalizado como respuesta al delito y al infractor reacciones eminentemente punitivas. Si bien, no existe abundante literatura que apoye esta tesis, dado el escaso desarrollo criminológico de nuestro país, una rápida revisión de la legislación y de su implementación como la realizada, nos lleva a concluir que, al menos en el siglo pasado, las nociones de rehabilitación y de la función preventiva especial positiva del castigo, no constituyeron ejes fundamentales de la legislación penal. Así, si en alguna medida logró penetrar el positivismo en la legislación, fue básicamente a través de su corriente peligrosista, mediante modificaciones como las analizadas. Tal fenómeno de cierta forma es esperable, considerando el precario desarrollo económico del país durante la mayoría del S.XX, y aun más, teniendo presente nuestras circunstancias histórico-políticas que distanciaron al país, por distintas razones, de dichos avances. En la misma línea, y siendo el mejor ejemplo la reforma procesal penal como manifestación de una convergencia de intereses, debemos recordar que casi en paralelo con su implementación, se estaba reformando el Código Penal, aprobándose leyes tendientes a endurecer la respuesta punitiva frente a determinados tipos penales, ${ }^{167}$ cuestión que a su vez se agudizó durante la década pasada. ${ }^{168}$ Esto en definitiva significó, que los intentos por hacer un uso racional de la pena privativa de la libertad, mediante la introducción de elementos de diversión del sistema, se vieran mitigados en las sucesivas reformas, generando un negativo impacto en las tasas de prisionización.

Finalmente, del análisis político criminal de las últimas décadas en Chile, resulta evidente la necesidad de coincidir con Diez, en el sentido de constatar el lugar protagónico que sigue teniendo la delincuencia clásica en nuestro diseño, no obstante los profundos cambios observados en esta arena. De esta forma, fuera de algunas excepciones, encontramos que en éste último período ha habido una intensificación de las legislaciones penal y procesal penal, orientadas a obtener un recrudecimiento del tratamiento de la delincuencia clásica,

\footnotetext{
${ }^{164}$ DAMMERT, "Violencia criminal", cit. nota $n^{\circ} 41$, p. 18.

${ }^{165}$ Ver en Anexo gráfico $\mathrm{N}^{\mathrm{o}} 2$.

${ }^{166}$ Ver en Anexo tabla $N^{\circ} 2$ y gráfico No 3.

${ }^{167}$ Véase supra, p. 10.

${ }^{168}$ Véase supra, pp.12-18.
} 
Polit. crim. Vol. 7, № 13 (Julio 2012), Art. 3, pp. 94 - 146.

[http://www.politicacriminal.cl/Vol_07/n_13/Vol7N13A3.pdf]

principalmente aquélla que atenta contra la vida, o la propiedad, así como la vinculada con los delitos sexuales. Lo anterior no implica apuntar a una ausencia completa de una legislación destinada a castigar la delincuencia económica, pues como se vio con anterioridad es posible rastrear algunas importantes modificaciones en esta materia, como es el caso de la Ley de responsabilidad penal de las personas jurídicas. Sin embargo, la regulación de dicho cuerpo legal deja entrever el carácter "piloto" de la citada legislación, principalmente considerando el restringido catálogo que la misma contempla, a saber los delitos de lavado de activos, financiamiento del terrorismo y delitos de cohecho, que a su vez cuentan con una escasa aplicación práctica. Así, como afirma Hernández, el catálogo resulta "extraordinariamente restringido, que en lo fundamental abarca sólo las materias respecto de las cuales existía obligación internacional de sancionar a las personas jurídicas (...), no obstante que durante la tramitación de la ley se hizo presente reiteradamente que quedaban fuera del catálogo los delitos de mayor trascendencia relacionados con la actividad empresarial". ${ }^{169}$ En efecto, este cuerpo legal no contempló aquellos delitos contra la salud pública y el medio ambiente y, en el ámbito de la corrupción, las figuras del fraude al Fisco, la negociación incompatible y la violación de secretos, ${ }^{170}$ que entre otras, hubiese resultado pertinente incluir, considerando sus ámbitos de acción y las mayores posibilidades de lesión de bienes jurídicos en dichas esferas. Lo anterior deja en evidencia la escasa relevancia que nuestro legislador ha prestado a la tipificación de conductas orientadas a perseguir y castigar de manera más enérgica aquellas conductas asociadas a la delincuencia económica.

Para finalizar el presente análisis resulta importante destacar que estos cambios en nuestra política criminal no sólo han tenido un efecto simbólico, sino que también en la práctica se ha concretado en un aumento explosivo de la población privada de su libertad. En ese sentido, resulta sencillo rastrear los efectos de la implementación de la reforma procesal en el sistema penitenciario, considerando que en 2005 dicha modificación se extendió a todo el país, al momento en que se producía un incremento exponencial del número de personas condenadas. Sin embargo, no es fácil efectuar el mismo ejercicio, tratándose de las fértiles reformas al Código Penal, a sus leyes especiales, y al Código Procesal Penal, aun cuando se pueda aventurar un efecto no sólo en término de la mayor cantidad de personas recluidas, sino también en la duración media de las condenas, cuestión que podría ser dilucidada en estudios más profundos sobre la materia.

En ese sentido, y siguiendo a Larrauri, ${ }^{171}$ que utiliza el término "punitivo" como sinónimo de tasas de encarcelamiento, no cabe duda que Chile puede ser catalogado como punitivo considerando sus altas tasas de prisionización, en comparación con otros países de región y también a nivel mundial, ${ }^{172}$ donde no existe una correlación directa con las cifras delictuales que de cierta forma justificarían ese aumento. ${ }^{173}$ Así, como se señaló, precisamente a partir de 2005, se registró un aumento explosivo de la cantidad de personas

\footnotetext{
${ }^{169}$ HERNÁNDEZ, Héctor "La introducción de la responsabilidad penal de las personas jurídicas en Chile", Política Criminal, Vol. 5, No 9 (Julio 2010), Art. 5, 207-236, p. 216.

${ }^{170}$ Historia de Ley $N^{\circ} 20.393$, preparada por la Biblioteca del Congreso Nacional, p. 35.

${ }^{171}$ LARRAURI, Elena “La Economía política del castigo”, Revista de Estudios de la Justicia, N¹1, 2009.

${ }^{172}$ Ver en Anexo Tabla $\mathrm{N}^{\circ} 4$.

${ }^{173}$ Ver en Anexo Gráfico No 9.
} 
MORALES, Ana María. "La política criminal contemporánea:

Influencia en Chile del discurso de la ley y el orden".

encarceladas, mientras que desde el año 2003 se comenzaron a registrar bajas sistemáticas en los índices de victimización.

\section{Conclusiones}

El presente trabajo comenzó con algunas preguntas fundamentales que apuntaban básicamente en dos direcciones. Una de ellas buscaba determinar si las políticas penales establecidas en Chile en las últimas dos décadas podían ser clasificadas como punitivas. Con ese propósito, se describió el desarrollo criminológico y político criminal del país, durante el siglo XX y hasta finales de década pasada. En esa búsqueda se pudo apreciar que la mayoría de las políticas penales del siglo pasado estuvieron fuertemente inspiradas en el modelo positivista, en su vertiente denominada de la defensa social, aunque en la práctica, más allá de la intención de los legisladores de la época, poco se puede apreciar de la materialización del modelo resocializador en nuestro país, imperando con mucha mayor fuerza las nociones peligrosistas de esa vertiente. Aun más, y como lo precisaron algunos autores, la política criminal chilena en el siglo XX, salvo excepciones, se caracterizó por su precariedad, su énfasis retributivo, y su severidad como respuesta. Por otro lado, en relación a la política criminal contemporánea, se pudo observar en las últimas dos décadas una fuerte tendencia a la politización del discurso asociado al control del delito, el que a su vez se vio plasmado en fértiles modificaciones legales, tendientes a endurecer la respuesta en términos de la persecución y a aumentar la severidad de las sanciones de determinados tipos penales.

La segunda perspectiva de este ensayo buscó entender por qué algunas jurisdicciones entregan respuestas punitivas en esta materia, y explorar además las razones que explican la adopción de medidas de control del delito con similares características en Chile. Con este objetivo, se analizó el trabajo desarrollado por algunos académicos, cuyas construcciones se basan fundamentalmente en la configuración de un nuevo modelo, basado en cambios de carácter estructural, como parte de las manifestaciones de la llamada "modernidad tardía". En particular, fueron explorados los fenómenos vinculados a la generación de "sociedades de riesgos" en una búsqueda permanente de la seguridad, y su antonimia representada por la inseguridad y sus consecuencias. En ese contexto, se examinaron aspectos distintivos de los modelos contemporáneos de control del delito, caracterizados por la preponderancia de iniciativas que otorgan un rol protagónico a las víctimas, la incorporación de estilos de gerenciamiento a los dispositivos legales e institucionales, a lo que se suma la politización y convergencia de los discursos en esta materia. Por otro lado, como argumentan algunos de los autores analizados, aun cuando se pueden encontrar signos importantes de modernización en esta arena, tendiente a hacerse cargo de la delincuencia socioeconómica en consonancia con los fenómenos asociados a la globalización y la creación de nuevos riesgos, lo cierto es que la política criminal contemporánea sigue teniendo como paradigma fundamental el abordaje y los modos de combatir la delincuencia clásica. De esta forma, los modelos actuales se caracterizan por una búsqueda permanente de instrumentos penales en orden a dar respuestas más severas, mediante técnicas tendientes a adelantar los momentos de punición, elevar las penas y generar herramientas que aseguren la inocuización de aquellos casos de delincuencia reiterada. Esta concepción, a su vez, generalmente es acompañada de altas tasas de miedo al delito y de la percepción de una opinión pública que 
reclama intervenciones más drásticas en estas materias, las que operan como una suerte de elementos justificadores.

En el caso de Chile, la situación político criminal sin duda no es ajena a las construcciones teóricas levantadas para explicar los cambios que se realizan en la misma línea en otras legislaciones. De tal forma, en mayor o menor medida, varios de los indicadores de cambio expuestos se encuentran presentes en el desarrollo de nuestra política criminal. En particular, un elemento llamativo de nuestra realidad dice relación con el exacerbado miedo al delito, el que se exhibe en tasas bastantes más elevadas que aquéllas observadas en los países desarrollados, y que son examinados de forma reiterada en las obras analizadas en este ensayo. En ese sentido, nuestra realidad es más asimilable al contexto latinoamericano que presenta altas cifras de miedo al delito y que, incluso en la mayoría de sus casos, son extremadamente alarmantes. Considerando lo anterior, resultaría atingente la búsqueda de explicaciones teóricas adicionales que pudieran indagar acerca de la realidad regional descrita, vinculándola a variables particulares de los países que la componen, como es el caso de sus altas tasas de victimización, de sus contingencias políticas, y de ciertos factores macrosociales, como la inequidad. Es por eso que, si bien es posible en la región encontrar autores que han buscado explicar esta situación, sus estudios aún son germinales. ${ }^{174}$

Por otro lado, como se ha expuesto, la inseguridad de la población a menudo se asocia a la creación de nuevos riesgos o a la visibilización de otros existentes que de cierta forma potencian la incertidumbre que caracteriza a los tiempos actuales. Esto, en la arena penal, se ha traducido en la incorporación de nuevos tipos que reconocen dichos riesgos, y en una adaptación de la justicia criminal y de la investigación criminológica a una estructura orientada a la detección de aquellos perfiles más riesgosos. Sobre el particular, lo cierto es que en nuestro país, efectivamente es posible rastrear la existencia de legislación novedosa, tendiente a dar protección penal a esos nuevos intereses o a otros que antes no se consideraba relevante proteger. En la misma línea, aunque aún de manera incipiente tomando en cuenta el escaso desarrollo criminológico del país- es posible observar la adopción de estrategias en el contexto del proceso penal, tendientes a identificar a aquellos grupos que se presentan como fruto permanente de riegos, en congruencia con la línea cultivada por la criminología actuarialista.

Por otro lado, resulta importante reconocer la influencia que han tenido los movimientos de apoyo a los ofendidos del delito en nuestro país, considerando la relegación que presentaron dichos actores, especialmente bajo la vigencia del modelo inquisitivo. En ese sentido, si bien es relevante reconocer la importancia de recoger sus intereses en el diseño político criminal, es también criticable el que se utilice la herramienta penal en desmedro del debido proceso. En esa esfera, la demanda general en esta materia se ha dirigido a exigir un mayor castigo de los infractores, por sobre otro tipo de intervenciones tendientes a otorgarle la debida protección y prevenir la comisión de delitos, especialmente aquellos violentos y que generan gran conmoción, como es el caso de los homicidios cometidos en el contexto intrafamiliar. Por otro lado, la introducción de estrategias de gerenciamiento, ha permitido en el ámbito del proceso penal concretar de cierta forma el principio de última ratio, y ha

\footnotetext{
${ }^{174}$ Véase, DAMMERT/MALONE, "Fear of Crime", cit. nota n 149; OVIEDO, Enrique y RODRIGUEZ, Alfredo "Santiago, una ciudad con temor", Temas sociales N²6, agosto 1999.
} 
MORALES, Ana María. "La política criminal contemporánea: Influencia en Chile del discurso de la ley y el orden".

generado estrategias tendientes a lograr la diversión de aquellos casos de menor lesividad, lo que sin duda es deseable y necesario. Sin embargo, se debe tener claro los problemas a los que nos podemos ver enfrentados, cuando la generación de estos mecanismos de gerenciamiento, son diseñados o utilizados de manera que operen regresivamente respecto de determinados grupos de población, en especial aquella más vulnerable, como por ejemplo los jóvenes pertenecientes a estratos socioeconómico bajos.

En la misma línea, es interesante reconocer el nivel de politización del debate en materia del control del delito, desarrollado a partir de finales de la década de los 90 en nuestro país, y observar cómo ha sido utilizado éste en la estrategia electoral. En ese sentido, es importante destacar la influencia de discursos asociados a demandas de la ley y el orden en la configuración de la política criminal. Sin embargo, también es necesario dar cuenta como lo recalcan diversos autores- que en la actualidad más que diferencia, se observa una convergencia en los discursos, lo que muchas veces a llevado a los candidatos a enfrascarse en competencias sobre quién se muestra más enérgico en el combate al delito. Asimismo, y en consonancia con el abandono del juicio de expertos, destacado por varios autores, las propuestas en esta área, generalmente distan bastante de la línea de las investigaciones criminológicas contemporáneas que han logrado identificar estrategias de reducción del delito, principalmente en materia de prevención y de ejecución penal, basadas en la evidencia de lo que funciona.

Por otro lado, es sencillo constatar que nuestra política criminal, en consonancia con los citados discursos, ha ido en la línea de punir con mayor energía a la denominada delincuencia clásica y entregar herramientas para confinar a aquellos infractores persistentes -aunque sea de manera transitoria, mediante una medida cautelar- que a juicio del legislador constituyen un "peligro para la seguridad de la sociedad", lo que a su vez recoge criterios asociados a una incapacitación selectiva.

Adicionalmente, es necesario tener presente que, en el caso chileno, el discurso asociado a demandas de la ley y el orden no apareció como estrategia frente a un problema artificial. Esto pues, la información disponible -con todas las falencias asociadas a la falta de sistematización- muestra efectivamente aumentos importantes de las denuncias a finales de la década de 90, en especial de los delitos contra la propiedad. De esta forma, el discurso asociado a una mayor dureza político criminal apareció como una repuesta pragmática al problema. En ese sentido, resulta por un lado complejo el que se utilicen estas herramientas como la principal estrategia de reacción del delito, y por el otro, que se continúen invocando de manera majadera, como se ha observado en los últimos períodos electorales, aun cuando las cifras de victimización se mantengan estables.

Asimismo, es necesario destacar a partir de la revisión efectuada en el primer capítulo, cómo en nuestro país, tradicionalmente la respuesta política criminal ha estado asociado a respuestas que no necesariamente se vinculan con los fines de prevención especial positiva y reinserción. Esto puede explicarse en cierta medida entendiendo que el apogeo de las corrientes resocializadoras se produjo en los países desarrollados en la década de los 60, período en el cual, como lo resaltan algunos autores, se observó en nuestro país un escaso desarrollo político criminal y criminológico, enfocándose el ámbito de las políticas públicas 
Polit. crim. Vol. 7, № 13 (Julio 2012), Art. 3, pp. 94 - 146.

[http://www.politicacriminal.cl/Vol_07/n_13/Vol7N13A3.pdf]

en otras áreas. De esta forma, considerando además nuestro contexto histórico político en esa década y la que le sucedió -cuando a su vez de produjo el desmoronamiento de esta corriente-, resulta evidente constatar un pobre traspaso de esta filosofía a nuestra realidad. Es así como, más allá de la escasa literatura que pudo haberla absorbido, lo cierto es que el discurso de la resocialización no logró penetrar con fuerza a las instituciones de ejecución penal.

Finalmente, de manera de efectuar un juicio general de la política criminal chilena, y respondiendo a algunas de las preguntas formuladas al comenzar este ensayo, es posible señalar que Chile puede ser catalogado como un país "punitivo", donde las altas de prisionización y sus oscilaciones, no se correlacionan con los índices de victimización que presenta el país. Esto sin duda se encuentra en consonancia con la literatura criminológica que ha mostrado cómo el aumento de encarcelamiento puede coexistir con un marcado descenso del delito, ${ }^{175}$ lo que afirma que el aumento desproporcionado de personas en prisión, no responde directamente a incrementos en la comisión de delitos, sino que además del número de delitos, "hay una decisión política de cómo reaccionar a ellos". ${ }^{176}$

Este escenario es complejo en la medida que no se trata sólo de cambios simbólicos que han provocado hipertrofias permanentes en nuestra legislación político criminal. Es así como es posible advertir, que las modificaciones en esta materia, desplegadas durante la última década, han tenido un fuerte impacto en la población privada de su libertad, y a su vez han generado tristes consecuencias, como fue el incendio que provocó la perdida de 81 personas que se encontraban recluidas en la cárcel de San Miguel, el 8 de diciembre de 2010. Fue así como estas reformas, encontraron lugares de reclusión con fuerte hacinamiento, precariedad en las condiciones de habitabilidad y escasos programas de reinserción, lo que de cierta forma hacía vaticinar la ocurrencia de hechos como el citado.

En ese sentido, como señala Petersilia para el caso norteamericano, las prácticas contemporáneas en esta materia no son más que el reflejo de una postura política diseñada para aparecer como "duro contra el delito". El problema en ese sentido, es que al final todos perdemos, pues pocos prisioneros logran retornar exitosamente a sus comunidades, generando en definitiva más delito, y produciendo un enorme gasto de los recursos presupuestarios destinados a concretarlas. ${ }^{177}$ En ese sentido, un adecuado cambio de giro, supone invertir mayores recursos en materia de prevención, especialmente en la terciaria, y el abandono de estrategias efectistas que en nada resuelven la esencia del problema de hacerse cargo del viejo dilema asociado a las "causas" del fenómeno criminal.

\footnotetext{
${ }^{175}$ Véase por ejemplo ZIMRING, Franklin, The Great American Crime Decline (Studies in Crime and Public Policy), Oxford University Press, 2007.

${ }^{176}$ LARRAURI, cit. nota $\mathrm{n}^{\circ} 171$, p. 60.

${ }^{177}$ PETERSILIA, Joan, When prisoners come home. Parole and Prisoner Reentry, Oxford University Press, 2003, p. vi.
} 
MORALES, Ana María. "La política criminal contemporánea: Influencia en Chile del discurso de la ley y el orden".

ANEXO ${ }^{178}$

Tablas y Gráficos

Tabla No 1 - Gráfico $\mathbf{N}^{\mathbf{0}} \mathbf{1}$

Total de personas recluídas 1980-2010

\begin{tabular}{|r|r|r|r|}
\hline \multicolumn{4}{|c|}{$\begin{array}{c}\text { Población total de personas recluidas en } \\
\text { Chile } \\
\text { 1980- 2010 }\end{array}$} \\
\hline Año & Personas & Año & Personas \\
\hline 1980 & 15.230 & 1996 & 23.567 \\
\hline 1981 & 14.726 & 1997 & 25.137 \\
\hline 1982 & 16.598 & 1998 & 26.871 \\
\hline 1983 & 18.525 & 1999 & 30.051 \\
\hline 1984 & 19.222 & $\mathbf{2 0 0 0}$ & 32.051 \\
\hline 1985 & 20.235 & 2001 & 32.464 \\
\hline 1986 & 21.348 & $\mathbf{2 0 0 2}$ & 33.261 \\
\hline 1987 & 22.813 & $\mathbf{2 0 0 3}$ & 34.543 \\
\hline 1988 & 24.354 & $\mathbf{2 0 0 4}$ & 34.592 \\
\hline 1989 & 24.497 & $\mathbf{2 0 0 5}$ & 35.501 \\
\hline 1990 & 22.593 & $\mathbf{2 0 0 6}$ & 38.007 \\
\hline 1991 & 20.872 & $\mathbf{2 0 0 7}$ & 42.033 \\
\hline 1992 & 20.258 & $\mathbf{2 0 0 8}$ & 46.974 \\
\hline 1993 & 20.490 & $\mathbf{2 0 0 9}$ & 50.923 \\
\hline 1994 & 20.962 & $\mathbf{2 0 1 0}$ & 51.441 \\
\hline 1995 & 22.027 & & \\
\cline { 1 - 3 } & & &
\end{tabular}

178 Agradezco a Nicolás Muñoz Correa, quien contribuyó a la realización de este ensayo, mediante la elaboración de varios de los gráficos que se contienen en el presente Anexo. 
Polit. crim. Vol. 7, № 13 (Julio 2012), Art. 3, pp. 94 - 146.

[http://www.politicacriminal.cl/Vol_07/n_13/Vol7N13A3.pdf]

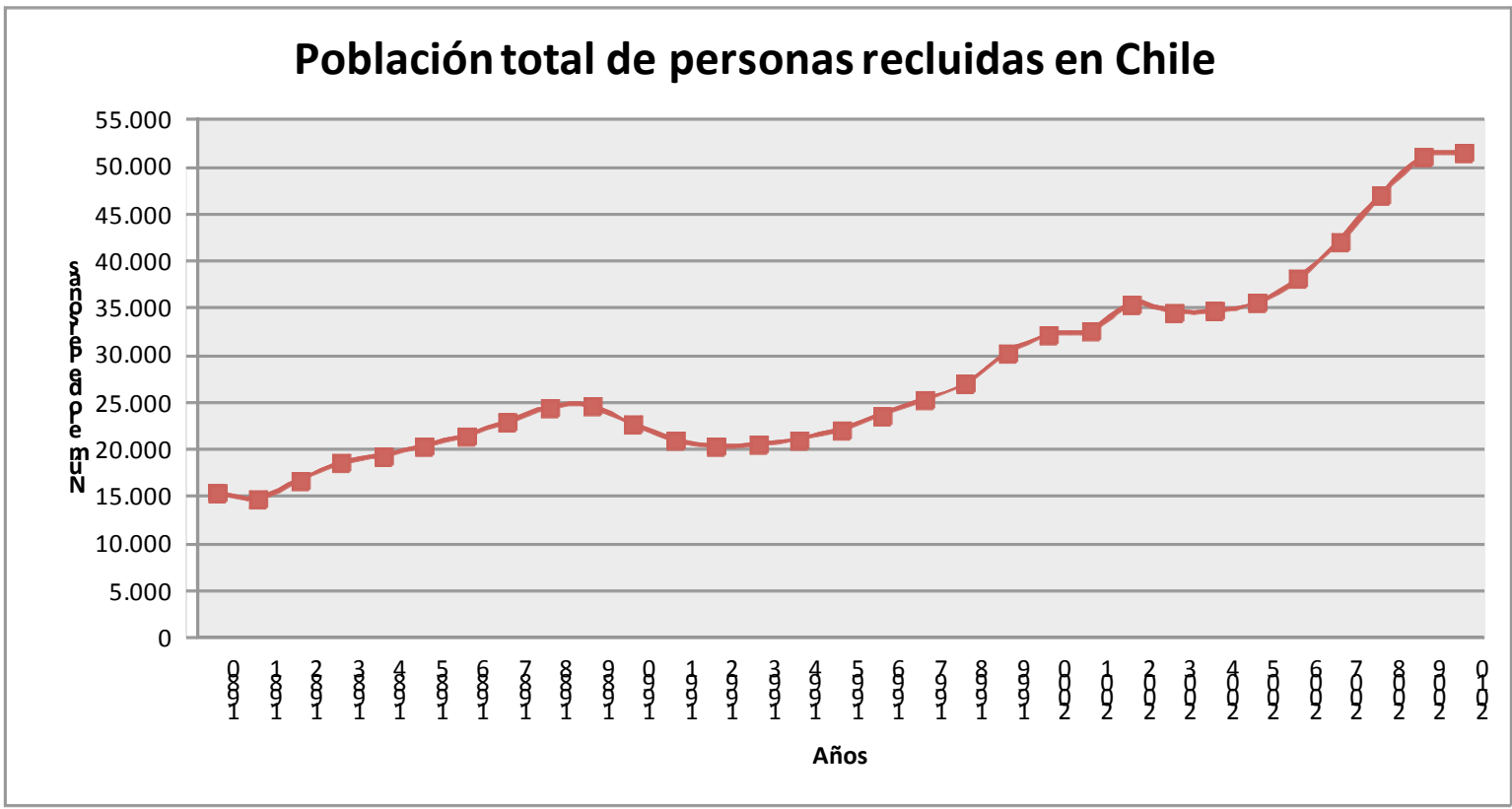

Fuente: Elaboración propia ${ }^{179}$

\section{Gráfico $\mathbf{N}^{0} 2$}

Denuncias delitos de mayor connotación social 1977-2003

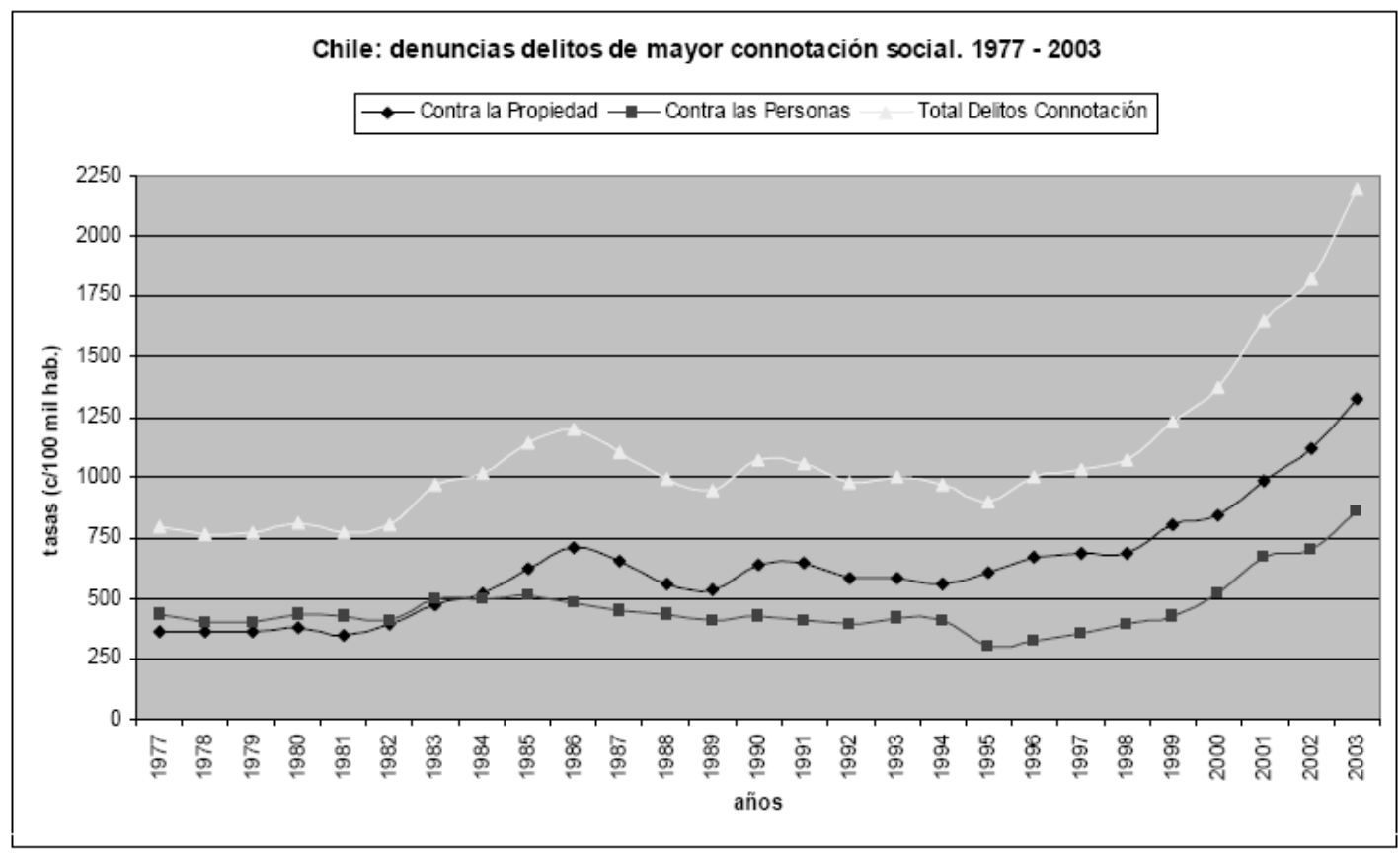

Fuente: Foro de expertos en Seguridad Ciudadana, 2004, p. 22.

${ }^{179}$ A partir de datos obtenidos de STIPPEL (1980- 1999) y Paz Ciudadana (2000-2010). STIPPEL, Jorg, Las Cárceles y la búsqueda de una política criminal para Chile, Santiago: LOM, 2006, p.34; y Balance de la delincuencia, Fundación Paz Ciudadana, 2010, p. 30. 
MORALES, Ana María. "La política criminal contemporánea: Influencia en Chile del discurso de la ley y el orden".

Tabla No 2 y Gráfico $N^{\circ} 3$

Victimización 2003-2010

\begin{tabular}{|c|r|}
\hline \multicolumn{2}{|c|}{$\begin{array}{c}\% \text { de Hogares Victimas de } \\
\text { algún Delito - ENUSC }\end{array}$} \\
\hline Año & Porcentaje \\
\hline 2003 & $43,0 \%$ \\
\hline 2005 & $38,3 \%$ \\
\hline 2006 & $38,4 \%$ \\
\hline 2007 & $34,8 \%$ \\
\hline 2008 & $35,3 \%$ \\
\hline 2009 & $33,6 \%$ \\
\hline 2010 & $28,2 \%$ \\
\hline
\end{tabular}

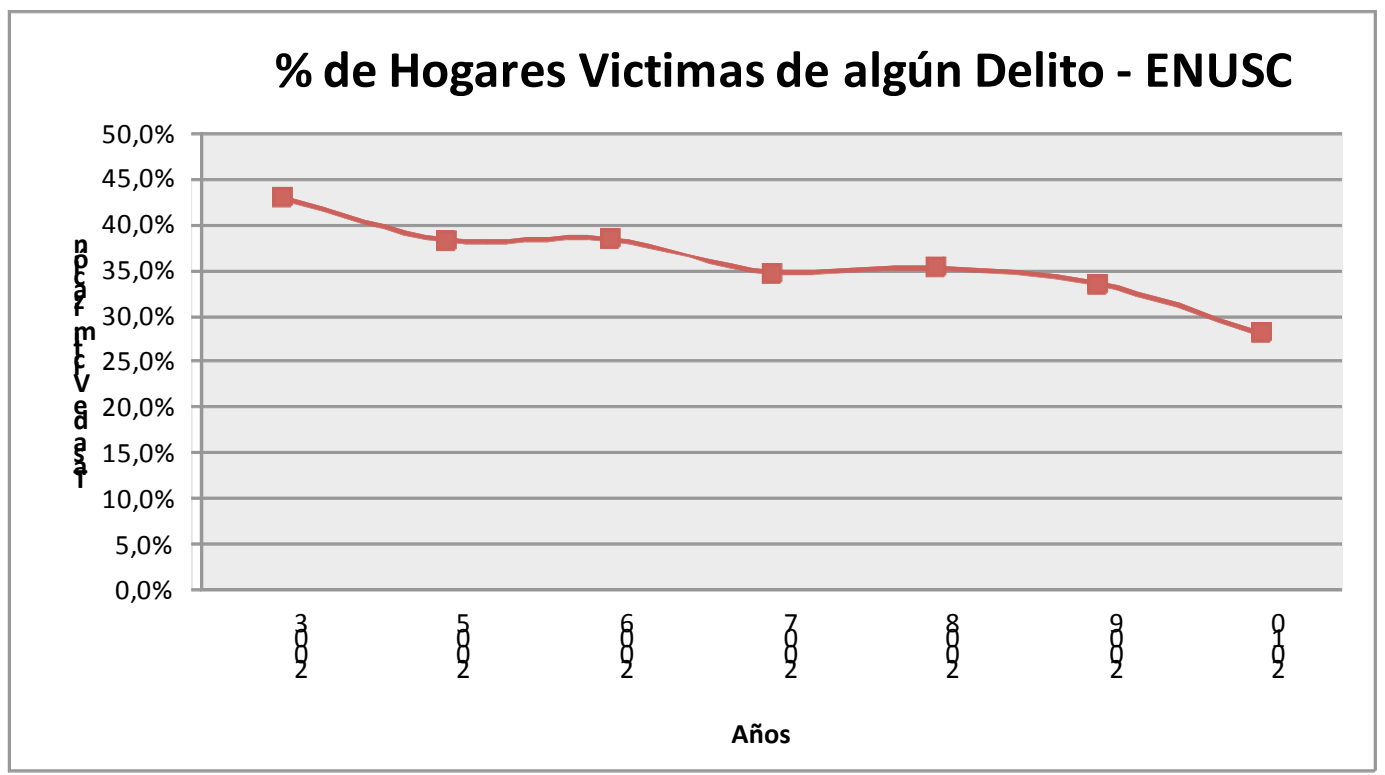

Fuente: Elaboración propia en base a datos de ENUSC. 
Polit. crim. Vol. 7, No 13 (Julio 2012), Art. 3, pp. 94 - 146.

[http://www.politicacriminal.cl/Vol_07/n_13/Vol7N13A3.pdf]

\section{Tabla No 3 y Gráfico $N^{\circ} 4$}

Probabilidad de ser víctima de delito en los próximos 12 meses 2003-2010

\begin{tabular}{|c|c|}
\hline \multicolumn{2}{|c|}{$\begin{array}{c}\text { Probabilidad de ser Víctima - } \\
\text { ENUSC }\end{array}$} \\
\hline Año & \multicolumn{1}{c|}{ Porcentaje } \\
\hline 2003 & $47,8 \%$ \\
\hline 2005 & $48,6 \%$ \\
\hline 2006 & $52,3 \%$ \\
\hline 2007 & $42,2 \%$ \\
\hline 2008 & $44,0 \%$ \\
\hline 2009 & $38,9 \%$ \\
\hline 2010 & $35,0 \%$ \\
\hline
\end{tabular}

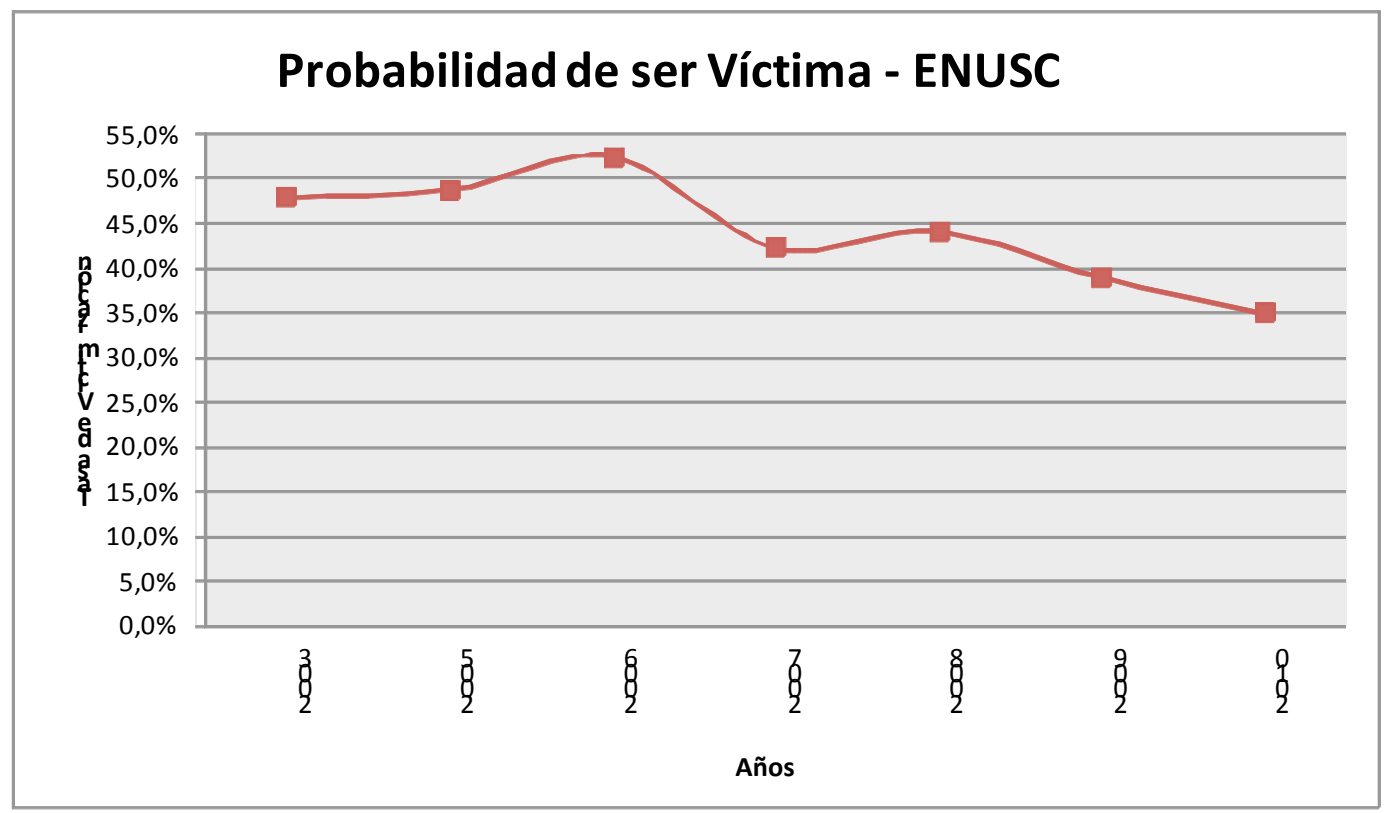

Fuente: Elaboración propia en base a datos de ENUSC. 
MORALES, Ana María. "La política criminal contemporánea:

Influencia en Chile del discurso de la ley y el orden".

\section{Gráfico No 5}

Evolución de la población atendida en Gendarmería de Chile en todos los sistemas 20002010

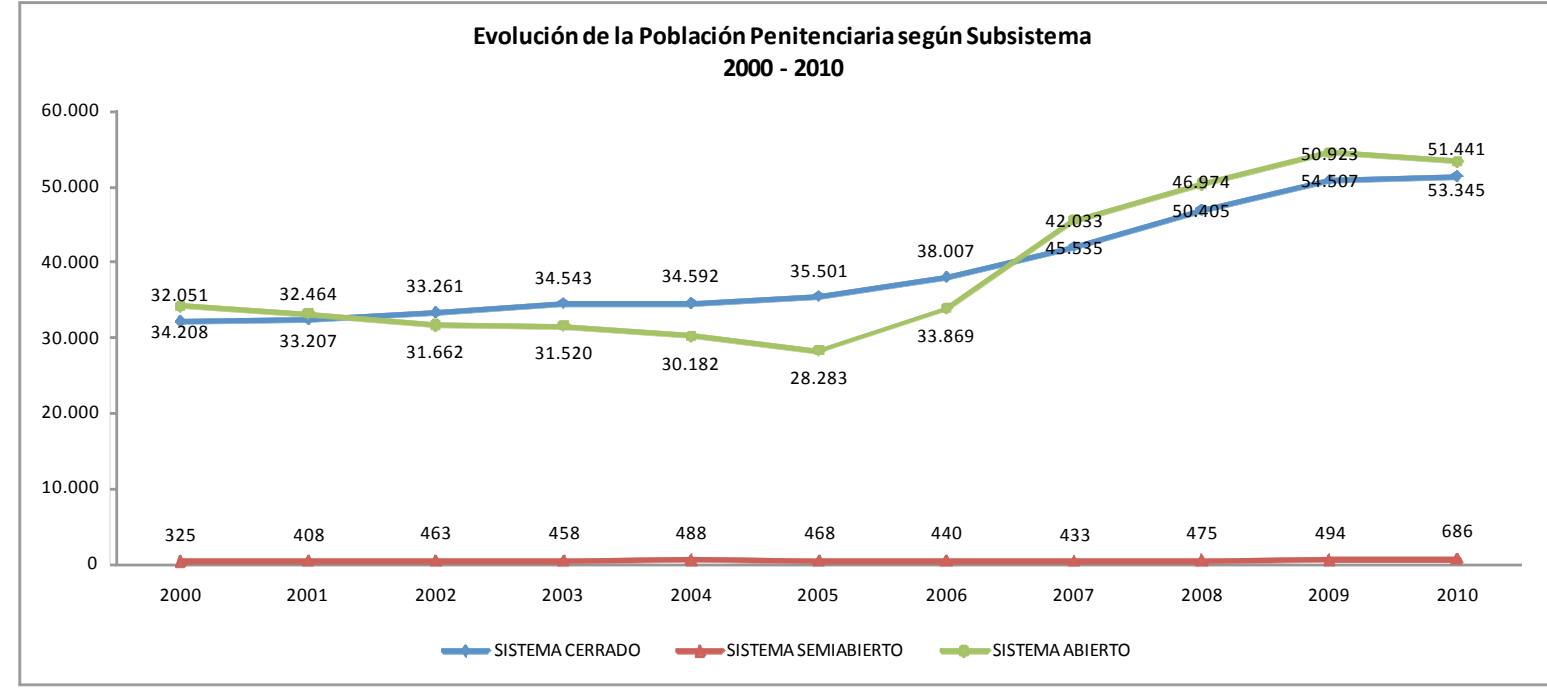

Fuente: Balance de la Delincuencia, Paz Ciudadana, 2010, p. 30.

\section{Gráfico $N^{0} 6$}

Evolución del temor en Chile 2000-2010

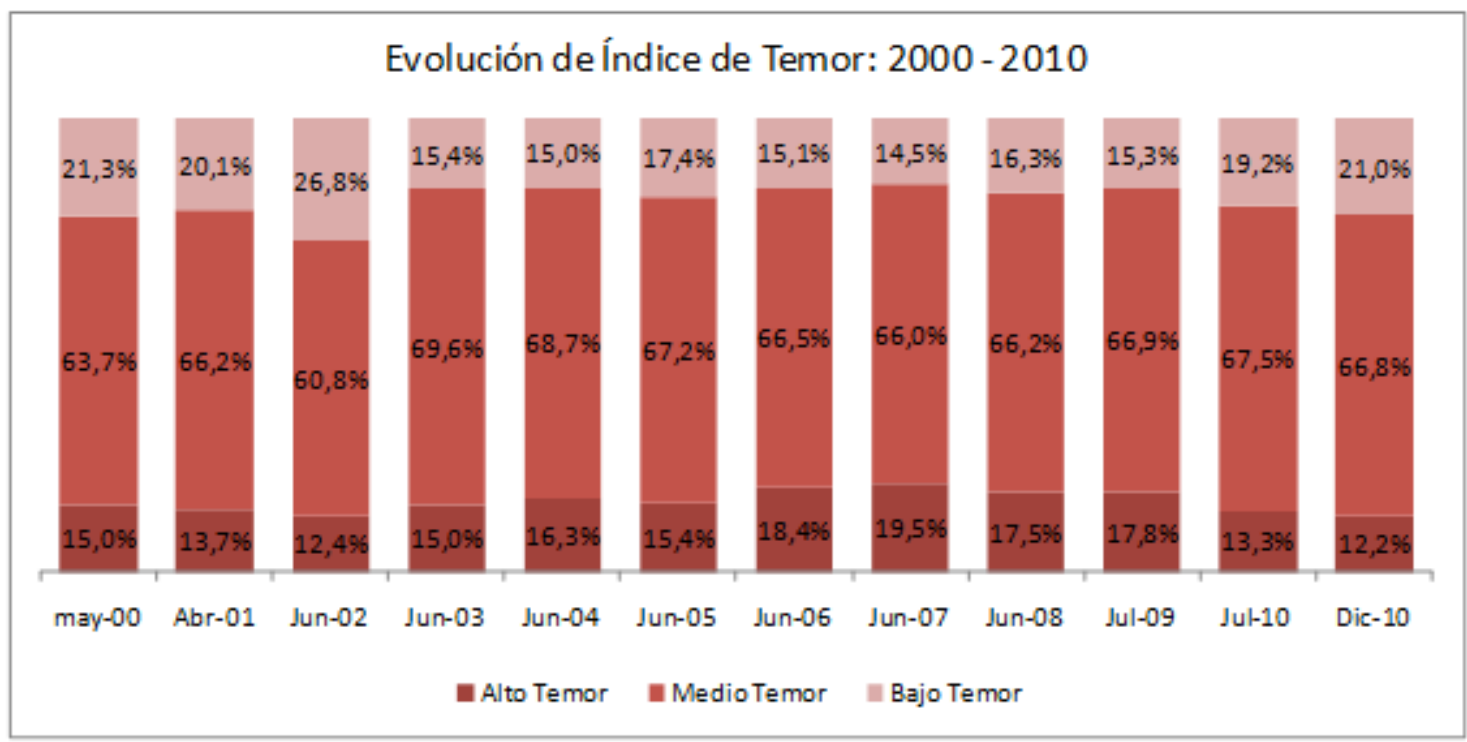

Fuente: Elaboración propia a partir de Índice Paz Ciudadana Adimark. 
Polit. crim. Vol. 7, № 13 (Julio 2012), Art. 3, pp. 94 - 146.

[http://www.politicacriminal.cl/Vol_07/n_13/Vol7N13A3.pdf]

\section{Gráfico $\mathbf{N}^{\circ} 7$}

Inseguridad en países desarrollados y Chile 2010

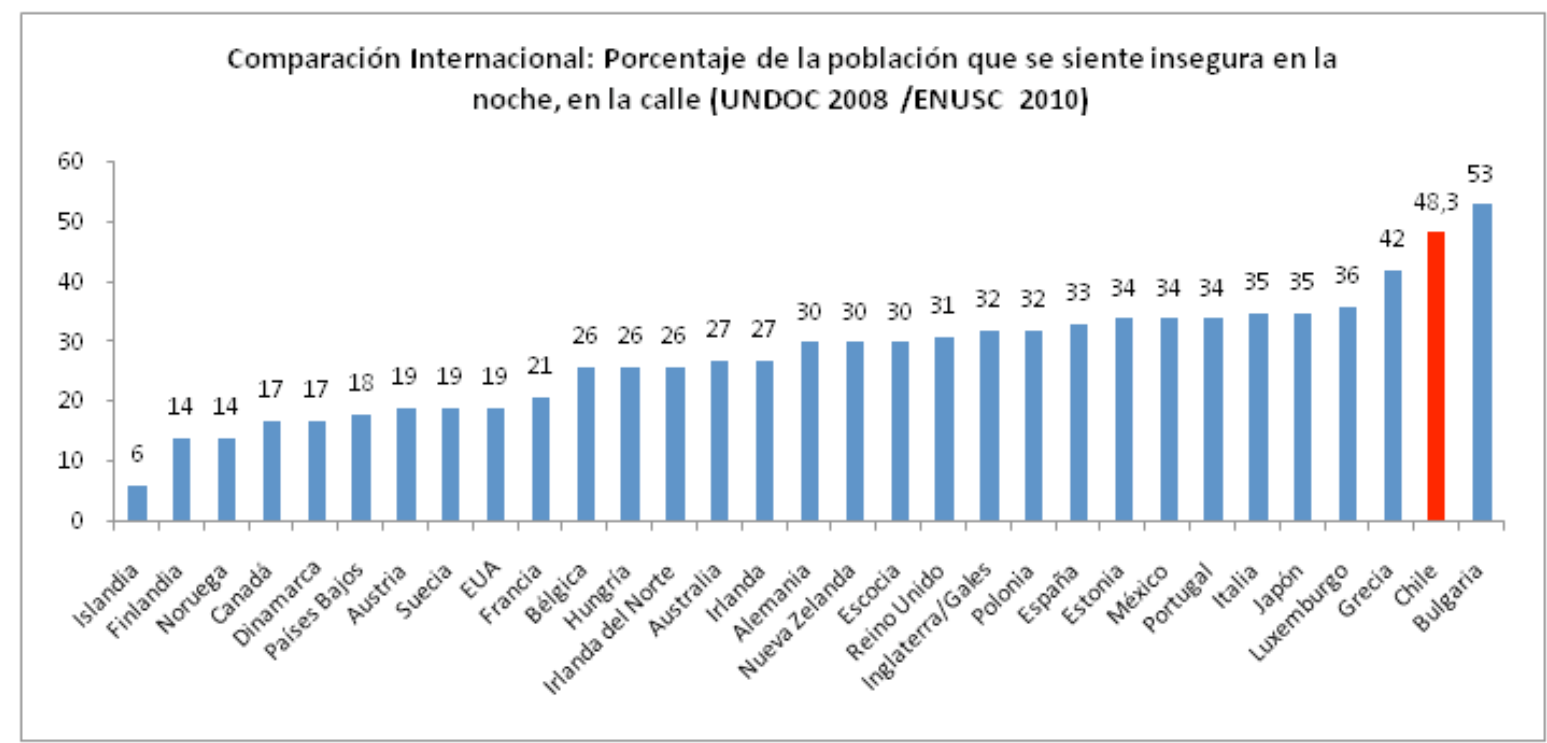

Fuente: Balance de la Delincuencia, Paz Ciudadana, 2010, p. 41.

\section{Gráfico $\mathrm{N}^{\circ} 8$}

Inseguridad en Centro y Latinoamérica 2010

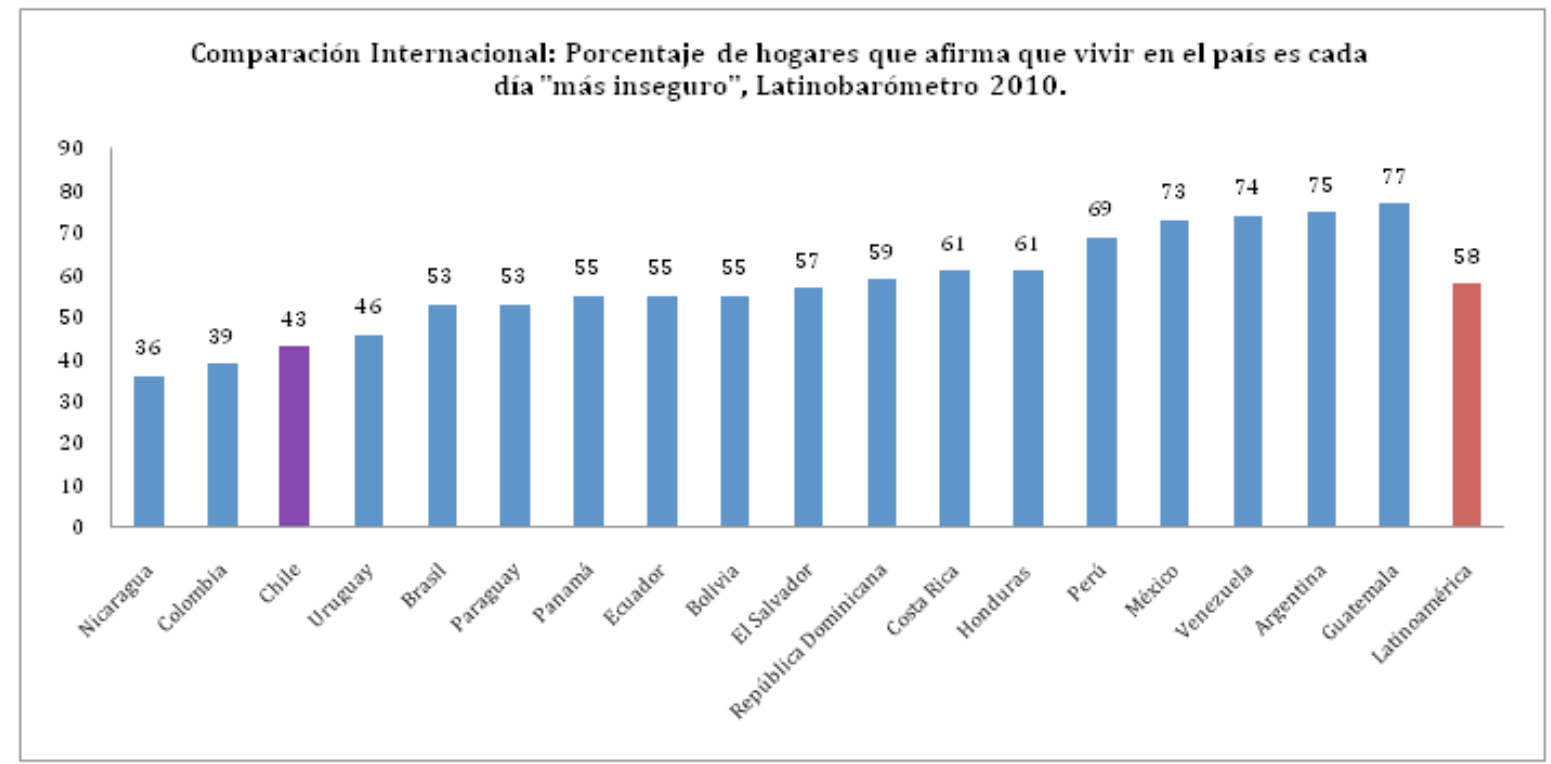

Fuente: Balance de la Delincuencia, Paz Ciudadana, 2010, p. 41. 
MORALES, Ana María. "La política criminal contemporánea: Influencia en Chile del discurso de la ley y el orden".

\section{Tabla $\mathbf{N}^{0} 4$}

Tasas mundiales de prisionización 2010

\begin{tabular}{|c|c|c|}
\hline \multicolumn{3}{|c|}{ MUNDIAL } \\
\hline PUESTO & PAís & TASA \\
\hline 1 & Estados Unidos & 743 \\
\hline 2 & Rusia & 577 \\
\hline 30 & Sudáfrica & 319 \\
\hline 35 & Chile & 304 \\
\hline 81 & España & 158 \\
\hline 90 & Reino Unido & 152 \\
\hline 144 & Francia & 96 \\
\hline 153 & Alemania & 85 \\
\hline 184 & Japón & 59 \\
\hline
\end{tabular}

\begin{tabular}{|c|c|c|}
\hline \multicolumn{3}{|c|}{ AMÉRICA DEL SUR } \\
\hline PUESTO & PAÍs & TASA \\
\hline 1 & Guayana Francesa & 365 \\
\hline 2 & Surinam & c.356 \\
\hline 3 & Chile & 304 \\
\hline 6 & Brasil & 253 \\
\hline 7 & Colombia & 180 \\
\hline 8 & Perú & 156 \\
\hline 9 & Argentina & 151 \\
\hline 12 & Bolivia & 87 \\
\hline 13 & Ecuador & 79 \\
\hline
\end{tabular}

Fuente: Elaboración propia en base a información del World Brief, Centre for Prison Studies, 2010.

Gráfico $N^{\circ} 9$

Victimización 2003-2010 -cantidad de personas recluidas 2000-2010.

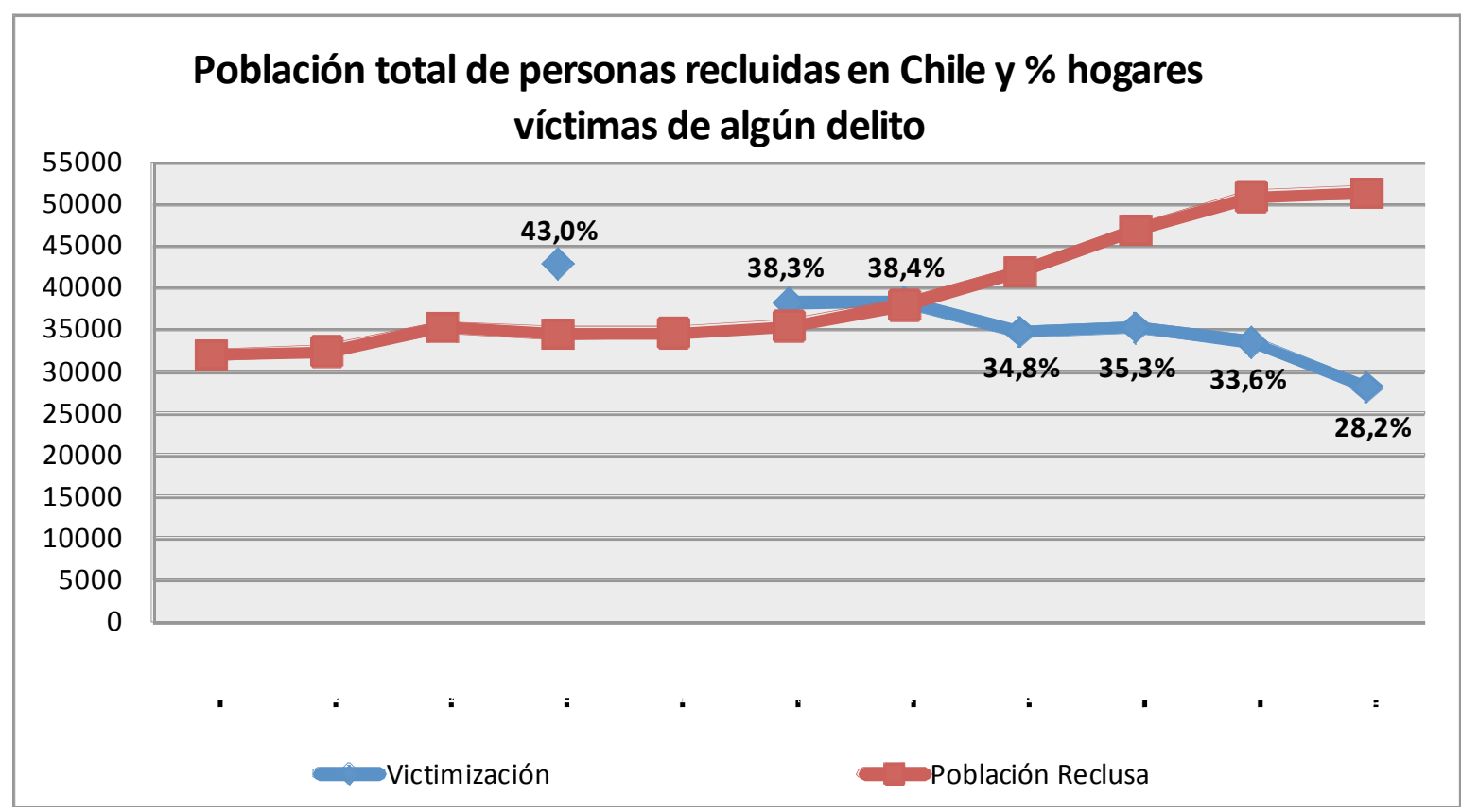

Fuente: Elaboración propia en base a datos de ENUSC y Balance de la delincuencia, Fundación Paz Ciudadana, 2010, p. 30. 
Polit. crim. Vol. 7, № 13 (Julio 2012), Art. 3, pp. 94 - 146.

[http://www.politicacriminal.cl/Vol_07/n_13/Vol7N13A3.pdf]

\section{BIBLIOGRAFÍA}

BARATTA, Alessandro, Criminología crítica y crítica del Derecho Penal, Buenos Aires Siglo XXI, 2002.

BECK, Ulrick, La sociedad de riesgo global, Madrid: S.XXI Editores, 2002.

BOTTOMS, Anthony, 'The Philosophy and Politics of Punishment and Sentencing', en CLARKSON, Chris y MORGAN, Rod (Eds.) The Politics of Sentencing Reform, Oxford: Clarendon Press, 1995.

BRAITHWAITE, John, Crime, Shame and Reintegration, Cambridge: Cambridge University Press, 1989.

BROWN, David, "Continuity, rupture, or just more of the "volatile and contradictory"? Glimpses of New South Wales penal practices behind and through the discursive" en: PRATT, J.; BROWN, D.; BROWN, M.; HALLSWORTH, S. and MORRISON, W. (Eds.) The New Punitiveness. Trends, theories and perspective, Cullompton: Willan, 2005.

CANDINA, Azun, "Seguridad Ciudadana y Sociedad en Chile Contemporáneo. Los delincuentes, las políticas y los sentidos de una sociedad", Revista de Estudios Históricos, 2(1), 2005. 2 Disponible en http://www.estudioshistoricos.uchile.cl/CDA/est hist_complex/0,1475,SCID\%253D1 5044\%2526ISID\%253D540\%2526PRT\%253D14999,00.html. [visitado el 24.07.2011].

CARNEVALI, Raúl, "Derecho Penal como Ultima Ratio. Hacia una política criminal racional", Ius et Praxis, Talca: Facultad de Ciencias Jurídica y Sociales de la Universidad de Talca, 14, N¹, 13, 2008.

, "Criterios para la punición de la tentativa en el delito de hurto a establecimientos de autoservicio. Consideraciones político-criminales relativas a la pequeña delincuencia patrimonial". Política Criminal, Santiago: Centro de Estudios en Derecho Penal de la Universidad de Talca, No 1, A2. 2006.

CASTILLO, Juan Carlos; MANZI, Jorge; LEAL, Paola; MADERO, Ignacio, "Percepción de riesgo, confianza en los Tribunales y actitudes hacia la penalización”, Informes Técnicos MIDE UC, 2011. Disponible en http://www.mideuc.cl/docs/informes/it1103.pdf. [visitado el 10.08.2011].

CAVADINO, Michael y DIGNAN, James, The Penal System, Londres: Sage, 1997.

CENTRO DE ESTUDIOS PÚBLICOS, Estudio Nacional de Opinión Pública, N 21. Disponible en www.cepchile.cl [visitado el 24.07.2011].

CHEVIGNY, Paul, "The Populism of Fear: Politics of Crime in the Americas", Punishment and Society, 5 (1): 77-96, 2003.

CHRISTIE, Nils, "Conflicts as property", British Journal of Criminology, 17 (1): 1-15, 1977.

CORREA, María José, "Demandas penitenciarias. Discusión y reforma de las cárceles de mujeres en Chile (1930-1950)". Historia (Revista del Instituto de Historia de la Pontifica Universidad Católica de Chile) 38(1:9-30, 2005. Disponible en http://www.scielo.cl/pdf/historia/v38n1/art02.pdf. [visitado el 24.07.2011].

DAMMERT, Lucía, "Violencia criminal y seguridad ciudadana en Chile", Serie Políticas Sociales, Santiago: Naciones Unidas, FLACSO, 2005. 
MORALES, Ana María. "La política criminal contemporánea: Influencia en Chile del discurso de la ley y el orden".

, "From Public Security to Citizen Security in Chile", en: BAILEY, J. y. DAMMERT, L. (Eds.), Public Security and Police Reform in the Americas, Pittsburgh: University of Pittsburgh Press, 2006.

, El sistema penitenciario en Chile: Desafios para el nuevo modelo público-privado, artículo preparado para ser presentado en la reunión anual de la Asociación de Estudios Latino Americanos, San Juan, Puerto Rico, 15 al 18 de Marzo, 2006. Disponible en http://www.flacso.cl/home/images/extension/congreso/lasa2006-sistemapenitenciario.pdf [visitado el 24.07.2011].

DAMMERT, Lucía y MALONE, Mary, "Fear of Crime or Fear of Life? Public Insecurities in Chile", Bulletin of Latin American Research, 22 (1): 79-101, 2003.

DÁVILA, Mireya, Seguridad Ciudadana: Actores y Discusión, Santiago: FLACSO-Chile, 2000.

DEL OLMO, Rosa, América Latina y su criminología, D.F México: Siglo veintiuno Editores, 1999.

DIEZ, José Luis, La política criminal en la encrucijada, Colección de Estudios y debates en Derecho Penal, No 3. Montevideo/Buenos Aires: B de F, 2007.

DUCE, Mauricio, "Diez años de Reforma Procesal Penal en Chile: Apuntes sobre su desarrollo, logros y desafíos", en: A diez años de la Reforma Procesal Penal: Los desafios del nuevo sistema, Santiago: Ministerio de Justicia, 2010.

FARRAL, Stephen; GRAY, Emily y JACKSON, Jonathan, "Theorizing the Fear of Crime: The Cultural and Social Significance of Insecurities about Crime", Experience and Expression in the Fear of Crime, Working Paper No. 5, ESRC Grant RES 00023 1108. Disponible en http://papers.ssrn.com/sol3/papers.cfm?abstract_id=1012393. [visitado el 24.07.2011].

FEELEY, Malcom, y SIMON, Jonathan, "The New Penology: notes on the emerging strategy of corrections and its implications", Criminology, Volume 30, Issue 4, pp. 449-474, 1992.

FEELEY, Malcom, "Crime, social order, and the rise of neo-Conservative politics", Theoretical Criminology 7 (1) 111-30, 2003.

FELLER, Claudio, "El derecho penal en la sociedad actual: un riesgo para las garantías penales", Revista de Derecho, Valparaíso: Pontificia Universidad Católica de Valparaíso, XXVI, Semestre I, 2005, pp. 41-52.

FERNÁNDEZ, José Ángel, "Los delitos de violación y estupro del artículo 365 bis del Código Penal: Una racionalización desde el mandato de Lex stricta y el principio de lesividad. Especial referencia a la introducción de dedos u otras partes del cuerpo", Revista Ius et Praxis, Talca: Facultad de Ciencias Jurídica y Sociales de la Universidad de Talca, v.13 n.2 105-135, 2007.

"El Nuevo Código Penal: una lucha por el discurso de la criminalidad", Política criminal, Santiago: Centro de Estudios en Derecho Penal de la Universidad de Talca, No 1-A5, p. 1-30, 2006.

FOUCAULT, Michel, Vigilar y Castigar, Madrid: Siglo XXI, 2005.

GARLAND, David, Punishment and Welfare, Aldershot: Gower, 1985. , La Cultura del Control, Barcelona: Gédisa, 2001.

GIDDENS, Anthony, “The risk society: The context of British Politics" en: FRANKLIN, Jane (Ed.) The Politics of risk Society, Cambridge: Polity Press, 1998. 
Polit. crim. Vol. 7, № 13 (Julio 2012), Art. 3, pp. 94 - 146.

[http://www.politicacriminal.cl/Vol_07/n_13/Vol7N13A3.pdf]

GREENWOOD, Peter, Selective Incapacitation. Santa Monica: Rand Publications, 1982.

HALL, Stuart, Drifting to a Law and Order Society. Londres: Cobden Trust, 1980.

HERNÁNDEZ, Héctor, "La introducción de la responsabilidad penal de las personas jurídicas en Chile", Política Criminal, Santiago: Centro de Estudios en Derecho Penal de la Universidad de Talca, Vol. 5, No 9 (Julio 2010), Art. 5, pp. 207-236. , "Perspectivas Del Derecho Penal Económico En Chile", Persona y Sociedad, Santiago: Universidad Alberto Hurtado, XIX, N¹, 2005, pp. $101-134$.

, "El Derecho Penal chileno en el cambio de siglo: Ensayo de balance y perspectivas". Persona y Sociedad, Santiago: Universidad Alberto Hurtado, Vol XVIII, N², 213-236, 2004.

HIRSCH, Hans Joachim, "Acerca de la posición de la víctima en el Derecho Penal y en el Derecho procesal penal”, BOVINO, Alberto y PASTOR Daniel (Eds.), De los delitos $y$ de las víctimas, Buenos Aires: Ad-Hoc, 1992.

HOFER, María Eugenia, "Medidas alternativas a la reclusión en Chile", Conceptos, Santiago: Fundación Paz Ciudadana, No4, 2008. Disponible en http://www.pazciudadana.cl/docs/pub_20090519144838.pdf. [visitado el 24.07.2011].

HORVITZ, María Inés y LÓPEZ, Julián, Derecho Procesal Penal Chileno, Tomo I, Santiago: Editorial Jurídica, 2003.

JIMÉNEZ, María Angélica y MEDINA, Paula, Violencia contra la pareja. Mayores penas, mayor violencia. Santiago: Librotecnia, 2011.

JIMÉNEZ, María Angélica y SANTOS, Tamara, “¿Qué hacer con las alternativas a la prisión?, Nova Criminis, Santiago: Centro de investigaciones criminológicas de la Facultad de Ciencias Jurídicas y Sociales de la Universidad Central de Chile, $\mathrm{N}^{\mathrm{o}} 1$, 157-240, 2010.

JONES, Trevor y NEWBURN, Tim, Policy Transfer and Criminal Justice, Maidenhead: Open University Press, 2007.

KEMELMAJER, Aída, Justicia Restaurativa, Buenos Aires: Rubinzal-Culzoni, 2004.

KEMSHALL, Hazel, "Understanding risk in criminal justice", MAGUIRE, Mike (Ed.) Crime and Justice, Berkshire: Open University Press, 2003.

LARRAURI, Elena, "La Economía política del castigo", Revista de Estudios de la Justicia, Santiago: Centro de Estudios de la Justicia de la Facultad de Derecho de la Universidad de Chile, $\mathrm{N}^{\circ}$ 11, 2009.

Trotta, 2006.

, Criminología crítica y violencia de género. Barcelona: Editorial

LEÓN, Marco, "Los dilemas de una Sociedad cambiante: criminología, criminalidad y justicia en el Chile contemporáneo 1911-1965", Revista Chilena de Historia del Derecho 19: 223-277, 2003/2004.

MATUS, Jean Pierre, "Informe acerca de algunos aspectos que se han mostrado problemáticos en la aplicación práctica de la Ley N²0.000”, Ius et Praxis, Talca: Facultad de Ciencias Jurídica y Sociales de la Universidad de Talca, v.11 n.2 333350, Talca, 2005.

, "El Positivismo en el Derecho Penal Chileno. Análisis sincrónico y diacrónico de una doctrina de principios de del siglo XX que se mantiene vigente", Revista de Derecho, Valdivia: Facultad de Ciencias Jurídicas y Sociales de la Universidad Austral, 20 (1), 2007. 
MORALES, Ana María. "La política criminal contemporánea: Influencia en Chile del discurso de la ley y el orden".

, "La Doctrina penal de la (fallida) recodificación chilena del siglo XX y principios del XXI", Política Criminal, Santiago: Centro de Estudios en Derecho Penal de la Universidad de Talca, 5(9), 2010, pp. 143-206.

MINISTERIO DEL INTERIOR, Encuesta Nacional Urbana de Seguridad Ciudadana. Disponible en http://www.seguridadpublica.gov.cl/enusc 2010.html. [visitado el 24.07.2011].

, Estrategia Nacional de Seguridad Pública (20062010). Disponible en http://www.interior.gob.cl/filesapp/publica2.pdf. [visitado el 24.07.2011].

, Foro de expertos en Seguridad Ciudadana, 2004. Disponible en http://www.bcn.cl/carpeta_temas/temas_portada.2005-1027.0803577082/documentos_pdf.2005-10-27.3919290237. [visitado el 24.07.2011].

MINISTERIO DEL INTERIOR y DIRECCIÓN DE ESTUDIOS SOCIOLÓGICOS DE LA PONTIFICIA UNIVERSIDAD CATÓLICA DE CHILE (DESUC) Encuesta nacional de victimización por violencia intrafamiliar y delitos sexuales. Santiago de Chile, $2008 . \quad$ Disponible en http://www.seguridadpublica.gov.cl/files/presentacion_violencia_intrafamiliar_v2.pdf . [visitado el 24.07.2011].

OLIVER, Guillermo, "Análisis crítico de las últimas modificaciones legales en materia de hurto-falta", Revista de Derecho, Valparaíso: Pontifica Universidad Católica de Valparaíso, vol. 1, núm. XXVI, 2005, pp. 295-307.

ORGANIZACIÓN PARA LA COOPERACIÓN Y EL DESARROLLO ECONÓMICO, Panorama de la Sociedad, 2011. Disponible en: http://www.oecd.org/dataoecd/39/23/47572883.pdf. [visitado el 24.07.2011].

PAZ CIUDADANA, Índice Paz Ciudadana Adimark. Disponible en http://www.pazciudadana.cl/publs.php?show=CAT\&idCat=12. $\quad$ [visitado el 24.07.2011]. , Balance de la delincuencia, 2010. Disponible en http://www.pazciudadana.cl/docs/pub_20110607103119.pdf. $\quad$ [visitado el 24.07.2011].

PETERSILIA, Joan, When prisoners come home. Parole and Prisoner Reentry, Nueva York: Oxford University Press, 2003.

PHILLIPS, Coretta y BOWLING, Ben, "Racism, Ethnicity, Crime and Criminal Justice", en MAGUIRE, Mike; MORGAN, Rod; RAINER, Robert (Eds.) The Oxford Handbook of Criminology, Oxford: Oxford University Press, $3^{\circ}$ Ed., 2002.

PROGRAMA DE LAS NACIONES UNIDAS PARA EL DESARROLLO, Desarrollo Humano en Chile 1998. Las Paradojas de la Modernización, Santiago: PNUD, 1998. Disponible en http://www.desarrollohumano.cl/textos/sin1998/PDF\%201998/I\%20Cap1.pdf. [visitado el 24.07.2011].

RAMÍREZ, María Cecilia, "Delitos de abuso sexual: actos de significación sexual y de relevancia". Política Criminal, Santiago: Centro de Estudios en Derecho Penal de la Universidad de Talca, no 3, A4, 2007.

REINER, Robert, Law and Order, Cambridge: Polity Press, 2007.

RIOS, Erick, Experiencias de evaluación de riesgo y seguimiento en Chile, Santiago: Centro de Estudios de Justicia de las Américas, 2010. 
Polit. crim. Vol. 7, № 13 (Julio 2012), Art. 3, pp. 94 - 146.

[http://www.politicacriminal.cl/Vol_07/n_13/Vol7N13A3.pdf]

SILVA, Jesús María, "La expansión del Derecho Penal. Aspectos de la política criminal en las sociedades postindustriales", Colección de Estudios y debates en Derecho Penal, $\mathrm{N}^{\circ}$ 1. Buenos Aires: B de F, 2009.

SPARKS, Richard, "Degrees of Estrangement: The cultural theory of risk and comparative penology", Theoretical Criminology, 2001 (5): 159-176.

STIPPEL, Jorg, Las Cárceles y la búsqueda de una política criminal para Chile, Santiago: LOM, 2006.

WARNER, Kate; DAVIS, Julia; WALTER, Maggie; BRADFIELD, Rebecca, y VERMEY, Rachel, "Public judgment on sentencing: Final results from Tasmanian Jury Sentencing Study", Trends \& Issues in crime and criminal justice, Australian Institute of Criminology, $\mathrm{N}^{\circ}$ 407, 2011.

YOUNG, Jock, La sociedad Excluyente. Exclusión social, delito, y diferencia en la modernidad tardía. Madrid: Marcial Pons, 2003.

ZEDNER, Lucia, "Dangers of Dystopia in Penal Theory", Oxford Journal of Legal Studies 22 (2): 341-66, 2002.

ZIMRING, Franklin, The Great American Crime Decline (Studies in Crime and Public Policy), Nueva York: Oxford University Press, 2007. 